\title{
Climate change and Saharan dust drive recent cladoceran and primary production changes in remote alpine lakes of Sierra Nevada, Spain
}

\author{
Laura Jiménez ${ }^{1,2}$ (D) $\mid$ Kathleen M. Rühland ${ }^{3}$ (D) $\mid$ Adam Jeziorski $^{3}$ (D) $\mid$ John P. Smol ${ }^{3}$ (D) \\ Carmen Pérez-Martínez ${ }^{1,2}$
}

${ }^{1}$ Institute of Water Research, University of Granada, Granada, Spain

${ }^{2}$ Department of Ecology, Faculty of Science, University of Granada, Granada, Spain

${ }^{3}$ Paleoecological Environmental Assessment and Research Lab (PEARL), Department of Biology, Queen's University, Kingston, ON, Canada

\section{Correspondence}

Laura Jiménez, Institute of Water Research, University of Granada, Granada, Spain.

Email: laura.jimenez.liebanas@gmail.com

Funding information

Ministerio de Educación y Ciencia (MEC), Grant/Award Number: AP2007-00352;

Programa Nacional de Movilidad de

Recursos Humanos de Investigación (MICINN); Ministerio de Medio Ambiente (MMA), Grant/Award Number: 87/2007;

Ministerio de Economía, Industria y Competitividad (MINECO), Grant/Award Number: CGL2011-23483; Natural Sciences and Engineering Research Council of Canada

\begin{abstract}
Recent anthropogenic climate change and the exponential increase over the past few decades of Saharan dust deposition, containing ecologically important inputs of phosphorus $(\mathrm{P})$ and calcium (Ca), are potentially affecting remote aquatic ecosystems. In this study, we examine changes in cladoceran assemblage composition and chlorophyll- $a$ concentrations over the past 150 years from high-resolution, welldated sediment cores retrieved from six remote high mountain lakes in the Sierra Nevada Mountains of Southern Spain, a region affected by Saharan dust deposition. In each lake, marked shifts in cladoceran assemblages and chlorophyll- $a$ concentrations in recent decades indicate a regional-scale response to climate and Saharan dust deposition. Chlorophyll-a concentrations have increased since the 1970s, consistent with a response to rising air temperatures and the intensification of atmospheric deposition of Saharan P. Similar shifts in cladoceran taxa across lakes began over a century ago, but have intensified over the past $\sim 50$ years, concurrent with trends in regional air temperature, precipitation, and increased Saharan dust deposition. An abrupt increase in the relative abundance of the benthic cladoceran Alona quadrangularis at the expense of Chydorus sphaericus, and a significant increase in Daphnia pulex gr. was a common trend in these softwater lakes. Differences in the magnitude and timing of these changes are likely due to catchment and lake-specific differences. In contrast with other alpine lakes that are often affected by acid deposition, atmospheric Ca deposition appears to be a significant explanatory factor, among others, for the changes in the lake biota of Sierra Nevada that has not been previously considered. The effects observed in Sierra Nevada are likely occurring in other Mediterranean lake districts, especially in softwater, oligotrophic lakes. The predicted increases in global temperature and Saharan dust deposition in the future will further impact the ecological condition of these ecosystems.
\end{abstract}

KEYWORDS

chlorophyll-a, Cladocera, Daphnia, high mountain lakes, Saharan dust, Sierra Nevada, warming 


\section{1 | INTRODUCTION}

Mountainous areas are among the most sensitive environments to anthropogenic climatic change, as their high relief and steep gradients make them especially vulnerable to even modest meteorological changes (Diaz, Grosjean, \& Graumlich, 2003). In particular, Mediterranean high mountain ecosystems have been repeatedly identified as being susceptible to accelerated anthropogenic warming (Lionello, 2012; Pauli et al., 2012). This is due in part to increased summer mean air temperature and reduced annual precipitation heightening the risk of summer drought in the Mediterranean region (NoguésBravo, López-Moreno, \& Vicente-Serrano, 2012).

In addition to climate change, remote alpine ecosystems are also affected by many other environmental stressors, particularly anthropogenic aerial deposition. The southernmost regions of the Mediterranean are predominantly influenced by substantial atmospheric deposits of Saharan dust (Lequy, Conil, \& Turpault, 2012; Pey, Querol, Alastuey, Forastiere, \& Stafoggia, 2013), accounting for $\sim 50 \%$ of global dust production (Schütz, Jaenicke, \& Pietrek, 1981). Aerosols from the Sahara are transported mainly across the Atlantic (Carlson \& Prospero, 1972; Swap, Garstang, Greco, Talbot, \& Kållberg, 1992), but also to the Mediterranean region, with an estimated $80-120 \times 10^{6} \mathrm{t} /$ year of Saharan dust transported northward to Europe (D'Almeida, 1986). The amount of Saharan dust exported to the atmosphere has increased exponentially in recent decades as a consequence of droughts in North Africa (Prospero \& Lamb, 2003), human-induced desertification (Moulin \& Chiapello, 2006), and the development of commercial agriculture in the Sahel region (Mulitza et al., 2010). Saharan dust contains high amounts of phosphorus $(\mathrm{P})$ and calcium (Ca), among other elements (LoÿePilot, Martin, \& Morelli, 1986; Morales-Baquero, Pulido-Villena, \& Reche, 2013), and dust deposition may contribute significant inputs of $\mathrm{P}$ and $\mathrm{Ca}$ to a variety of ecosystems (Camarero \& Catalan, 2012; Morales-Baquero, Pulido-Villena, \& Reche, 2006; Ridame \& Guieu, 2002). The ecological effects of these inputs remain poorly understood.

Remote lakes are sensitive to both natural and anthropogenic factors (Adrian et al., 2009; Smol, 2008), and are often considered sentinels of environmental change (Williamson, Saros, Vincent, \& Smol, 2009). Sierra Nevada, located in the southeastern part of the Iberian Peninsula (Spain), is the southernmost mountain range of Europe (Figure 1). There are $\sim 50$ small alpine lakes situated between $\sim 2,800$ and 3,100 $\mathrm{m}$ asl and many of these have been analyzed in numerous limnological studies. Unlike many European mountain lakes that have a history of acidification (Alewell, Manderscheid, Meesenburg, \& Bittersohl, 2000; van Breemen \& Wright, 2004), Sierra Nevada lakes receive little acid deposition (Camarero et al., 1995), but these low productive, softwater lakes are influenced by

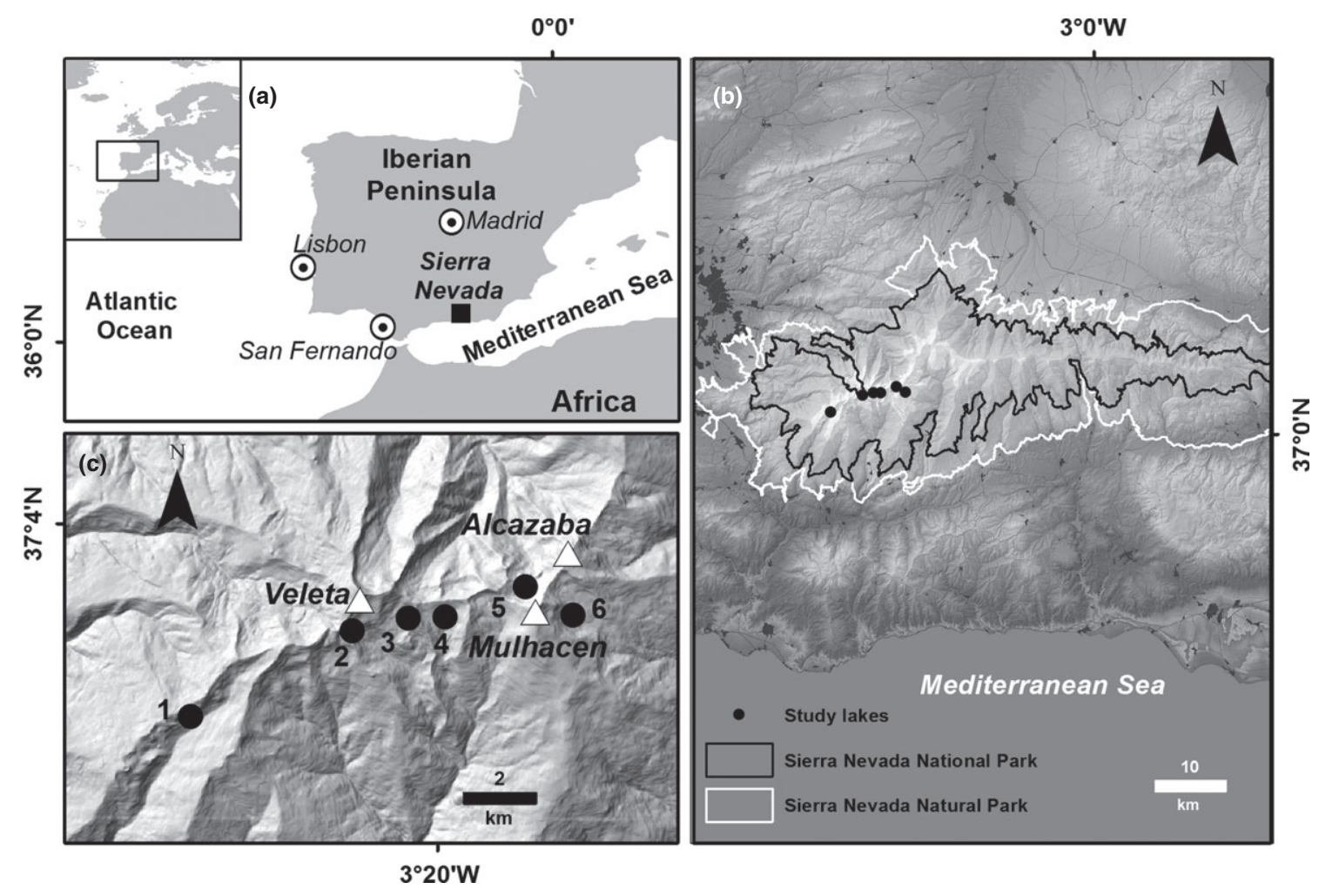

FIGURE 1 (a) The inset map and Iberian Peninsula map showing the location of the study area. (b) Map of the Sierra Nevada mountain range showing geographical locations of the six study lakes. Boundaries of the Natural and National Park are shown by white and black continuous lines, respectively. (c) Geographic locations of the six study lakes (circles; see Table 1 for further information). 1: Cuadrada (CD); 2: Aguas Verdes (AV); 3: Río Seco Superior (RSS); 4: Río Seco (RS); 5: Mosca (MC); 6: Borreguil (BG). Triangles represent the highest mountain peaks in the Sierra Nevada mountain range 
the deposition of nutrient-laden dust from the Sahara (particularly $\mathrm{P}$ and $\mathrm{Ca}$ fertilization). For example, the $\mathrm{Ca}$ input entering into Río Seco Lake from Saharan dust (input to the catchment plus direct input to lake surface area) has been estimated at $190 \mathrm{~kg}$ Ca per year, an amount sufficient to account for the entire lake Ca budget (Pulido-Villena, Reche, \& Morales-Baquero, 2006). The effect of Saharan dust deposition on lake biogeochemistry and chlorophyll content (Morales-Baquero, Pulido-Villena et al., 2006), on the pool of dissolved organic matter (Mladenov et al., 2011), and on bacterial activity (Reche et al., 2009) has been found to be significant. Interannual climate differences have been reported to affect water level and temperature in Sierra Nevada lakes (García-Jurado, JiménezGómez, \& Gómez, 2011; Villar-Argaiz, Medina-Sánchez, Cruz-Pizarro, \& Carrillo, 2001) and also modify phytoplankton and zooplankton biomass, nutrient availability (Barea-Arco, Pérez-Martínez, \& Morales-Baquero, 2001; Morales-Baquero, Carrillo, Barea-Arco, Pérez-Martínez, \& Villar-Argaiz, 2006; Pérez-Martínez, Jiménez, Moreno, \& Conde-Porcuna, 2013), and epilithic diatom communities (Sánchez-Castillo, Linares-Cuesta, \& Fernández-Moreno, 2008).

Despite ongoing limnological studies in Sierra Nevada lakes, the lack of long-term, continuous monitoring data makes it difficult to place current limnological surveys within a long-term context. For such perspectives, a paleolimnological approach using the archive of material preserved in lake sediments is required (Smol, 2008). Previous sedimentary studies in the Sierra Nevada have focused on millennial-scale trends of paleoclimatic and paleoenvironmental conditions, as well as human impacts in the highest lands of the massif through the analysis of physical and geochemical proxies (Anderson, Jiménez-Moreno, Carrión, \& Pérez-Martínez, 2011; Jiménez-Moreno, García-Alix, Hernández-Corbalán, Anderson, \& Delgado-Huertas, 2013; Oliva, Schulte, \& Gómez-Ortiz, 2011), highlighting the potential role of Saharan dust deposition on lake production during the mid-Holocene (Jiménez-Espejo et al., 2014; Oliva, Gómez-Ortiz, \& Schulte, 2010), as well as the effect of increasing temperatures on the disappearance of glacial ice from mountain cirques with post-Little Ice Age (LIA) warming (Oliva \& Gómez Ortiz, 2012). To date, the only paleolimnological investigation of biological changes over the past two centuries within Sierra Nevada lakes is a pigment analysis of Río Seco Lake (Jiménez, Romero-Viana, CondePorcuna, \& Pérez-Martínez, 2015). Little is known regarding the potential interactions between climate change and the deposition of Saharan dust on the biological communities of these remote lakes.

The Cladocera are an order of aquatic invertebrates whose remains preserve well in lake sediments and have been used extensively in a variety of paleolimnological analyses to study topics such as trophic dynamics (Manca, Torretta, Comoli, Amsinck, \& Jeppesen, 2007; Perga, Desmet, Enters, \& Reyss, 2010), water temperature (Fischer et al., 2011; Nováková, van Hardenbroek, \& van der Knaap, 2013), and lake water levels (Nevalainen, Helama, \& Luoto, 2013). Both the direct influence of climate warming and indirect climate-driven limnological changes (e.g., length of the icefree period and growing season, water level changes, changes in oxygen availability, thermal stability, or changes in chemical properties) may affect species distribution and dominance among cladoceran assemblages in alpine lakes (Kamenik, Szeroczyńska, \& Schmidt, 2007; Luoto \& Nevalainen, 2016). Acidification-induced declines in the lake water Ca concentration of many Canadian softwater lakes have been associated with declines in the abundance of Daphnia spp. (Jeziorski et al., 2008). Ca minerals are an important structural component for the development of cladoceran exoskeletons (Greenaway, 1985), and as members of Daphnia spp. have higher Ca content (\% dry weight) than many of their competitors, they are more vulnerable to changes in ambient Ca concentrations (Jeziorski et al., 2015; Jeziorski \& Yan, 2006). Although Saharan dust deposition affects large regions of the world (dubbed the "global dust belt" by Prospero, Ginoux, Torres, Nicholson, and Gill (2002)), the potential role of atmospheric Saharan Ca inputs on cladoceran populations, particularly Daphnia abundance, has not been investigated.

Here, we explore changes in chlorophyll- $a$ (and its main diagenetic products) concentrations and in the relative abundances of cladoceran microfossils in lake sediments to determine whether recent climate warming and Saharan dust deposition over the past $\sim 150$ years have affected Sierra Nevada lakes. We hypothesize that both of these environmental factors have had significant effects on these remote, softwater alpine lakes. Due to their geographic location, the lakes are exposed to large amounts of dust transported from Saharan Africa, but otherwise have naturally low $\mathrm{Ca}$ concentrations that may be limiting for some cladocerans, particularly certain Daphnia spp. (Ashforth \& Yan, 2008). Large-bodied, warm water cladoceran taxa may be favored over cold-tolerant, smaller taxa as a result of recent climate warming, which can be linked to warmer water temperatures, longer growing seasons, and increased primary production, the latter of which can also be influenced by increased atmospheric $P$ inputs. The Ca-rich Saharan dust inputs and evapoconcentration of lake $\mathrm{Ca}$, together with warming-induced increases in water residence time, is expected to favor $\mathrm{Ca}$ rich cladoceran taxa such as Daphnia spp.

To provide a regional assessment of the effects of recent warming and Saharan dust deposition, we strategically selected six alpine lakes to represent the range of lake types and environments present within Sierra Nevada. Our objective was to analyze changes within the sedimentary cladoceran assemblages and sedimentary chlorophyll- $a$ concentrations over the past $\sim 150$ years to test: (i) if the nature, magnitude, direction, and timing of changes in cladoceran assemblages are consistent with recent warming; (ii) if Daphnia relative abundance changes can be linked to variations in Saharan Ca deposition; and (iii) if changes in primary production (inferred through sedimentary chlorophyll-a) can be linked to warming and increased delivery of P-laden Saharan dust.

\section{2 | MATERIALS AND METHODS}

\section{1 | Site description}

In the Sierra Nevada mountains of SE Spain $\left(36^{\circ} 55^{\prime}-37^{\circ} 15^{\prime} \mathrm{N}, 2^{\circ} 31^{\prime}-\right.$ $3^{\circ} 40^{\prime} \mathrm{W}$; maximum altitude $3,482 \mathrm{~m}$ asl), there are $\sim 50$ small lakes of 
glacial origin at an elevation of $\sim 2,800-3,100 \mathrm{~m}$ asl (Figure 1; Castillo-Martín, 2009).

The predominant geologic substrate in these catchment basins is slow-weathering, metamorphosed siliceous bedrock, mainly micaschist with graphite and mica-schist with feldspar (Puga, Díaz de Federico, Nieto, \& Díaz Puga, 2007). The lakes are remote, located above the tree line, have poorly developed soils that do not support agriculture or forestry, and the vegetation surrounding some of the lakes is restricted to sparse meadows (alpine tundra). These glacial mountain lakes are typically shallow (maximum depth $<10 \mathrm{~m}$ ) and small (surface area $<1 \mathrm{ha}$ ). During summer, some of the lakes may become dry while others may experience variable reductions in their water level. This water level reduction becomes greater and longer lasting during warm and dry years relative to cold and wet years. Most lakes in this region have an open basin, usually with temporary surface inlets or outlets. Sierra Nevada summits experience a high mountain Mediterranean climate characterized by a warm and dry season (from June to October). The meteorological station at the summit $(2,507 \mathrm{~m}$ asl) reports a mean annual temperature of $4.4^{\circ} \mathrm{C}$ and total precipitation of $700 \mathrm{~mm}$, with $80 \%$ occurring as snow between October and April (Oliva et al., 2011).

Six lakes were strategically selected (Figure 1) for retrieving highresolution paleolimnological sedimentary records using the following criteria: (i) they are permanent water bodies with maximum depths $>2.0 \mathrm{~m}$; (ii) they have nonrocky bottoms; and (iii) they are representative of five different glacial valleys close to the mountain ridge of the Sierra Nevada to better characterize the regional variation in lake and valley types. We selected permanent lakes to ensure that the sediments were not affected by deflation and other processes related to air exposure or the extreme reduction in maximum depth as has been noted in some of the deeper Sierra Nevada lakes (e.g., La Caldera; Villar-Argaiz et al., 2001; Sánchez-Castillo et al., 2008). Short-term studies (de Vicente, Andersen, Hansen, Cruz-Pizarro, \& Jensen, 2010; Morales-Baquero, Carrillo et al., 2006) and field observations (Castillo-Martín, 2009; Linares-Cuesta, Olofsson, \& SánchezCastillo, 2007; Morales-Baquero, Carrillo, Reche, \& Sánchez-Castillo, 1999; Reche, Pulido-Villena, Morales-Baquero, \& Casamayor, 2005) indicate that the six study lakes have experienced only slight changes in water level over the past 20 years. CD and RSS lakes are currently closed basin systems, while the remaining lakes have surface inlets or outlets that frequently became dry at the end of summer. Although the six study lakes represent different lake types and environmental settings, they are all shallow, clear, and well-mixed lakes that are characterized by littoral habitat (i.e., no clearly differentiated profundal zone). The lakes are circumneutral to slightly acidic, and low in alkalinity and primary production (Table 1).

The ice-cover season for lakes in the Sierra Nevada region typically lasts from November to June; however, large interannual differences in the duration of ice cover have been linked to annual variations in climatic conditions (Barea-Arco et al., 2001; MoralesBaquero, Carrillo et al., 2006; Pérez-Martínez, Barea-Arco, CondePorcuna, \& Morales-Baquero, 2007). These shallow study lakes are fishless and do not thermally stratify during the summer. The six lakes, Río Seco (RS), Río Seco Superior (RSS), Aguas Verdes (AV), Borreguil (BG), Mosca (MC), and Cuadrada (CD), are within an $8 \mathrm{~km}$ radius, and with the exception of $M C$, are located on the south face of Sierra Nevada. The lakes are relatively remote, with local human activity currently limited to some sheep and cattle herding within the surrounding meadows during summer months. For $\sim 30$ years prior to the establishment of the Sierra Nevada National Park in 1999, there was also a mountain hut situated close to RS, and a dirt road passing near AV, RS, and RSS that experienced minor summer traffic activity. Additional chemical and biological details for the study lakes can be found elsewhere (Morales-Baquero \& Conde-Porcuna, 2000; Morales-Baquero et al., 1999; Pérez-Martínez et al., 2007; Reche, Pulido-Villena, Conde-Porcuna, \& Carrillo, 2001; Reche et al., 2005).

\subsection{Sediment coring and field measurements}

Sediment cores were collected during the summer of 2011 (except for RS, which was sampled in 2008) from the deepest area of each lake using a slide-hammer gravity corer (Aquatic Research Instruments, Hope, ID, USA) with an inner core-tube diameter of $6.8 \mathrm{~cm}$. All cores, with the exception of RS, were extruded on site at $0.25 \mathrm{~cm}$ intervals for the upper $5-10 \mathrm{~cm}$, and then at $0.5 \mathrm{~cm}$ intervals from 5 to $10 \mathrm{~cm}$ to the base of the core. The sediment core retrieved from RS was sectioned into $0.5 \mathrm{~cm}$ intervals for the entire core. Following extrusion, sediment samples were immediately sealed in sterile Whirlpak ${ }^{\circledR}$ bags, wrapped in a dark bag and placed in a cooler until they were transported to the University of Granada (Spain) where they were stored in a cold room at $\sim 4^{\circ} \mathrm{C}$ until analysis. Tube samplers $(6.7 \mathrm{~cm}$ diameter) of different lengths were used to collect an integrated sample of the whole water column from the deepest point of each lake and were analyzed for a suite of limnological variables following the techniques detailed in Barea-Arco et al. (2001) and Morales-Baquero, Carrillo, et al. (2006). Specific conductivity and $\mathrm{pH}$ were measured on site with a Waterproof PC $300 \mathrm{~m}$.

\section{3 | Sediment chronology}

Sediment cores were dated using gamma spectroscopy to measure the activities of radioisotopes and establish a chronology for the past 150 years. For each core, a selection of 15-20 sedimentary intervals was analyzed for ${ }^{210} \mathrm{~Pb}$ activity following the technique outlined in Schelske, Peplow, Brenner, and Spencer (1994). Chronologies for each core were calculated from excess ${ }^{210} \mathrm{~Pb}$ activities using the constant rate of supply (CRS) model (Appleby \& Oldfield, 1978). Additionally, ${ }^{137} \mathrm{Cs}$ was used as an independent chronological marker of 1963 (global nuclear weapons testing ban) and used to corroborate the ${ }^{210} \mathrm{~Pb}$ dates (Appleby, 2001). The RS core was analyzed at the Center for Research, Innovation and Technology (CITIUS), University of Seville, Spain and the other cores were analyzed at the Paleoecological Environmental Assessment and Research Laboratory 
TABLE 1 Location and environmental characteristics of the six study lakes in Sierra Nevada mountains

\begin{tabular}{|c|c|c|c|c|c|c|}
\hline & \multicolumn{6}{|l|}{ Lake (lake code) } \\
\hline & Río Seco (RS) & Río S. Superior (RSS) & Aguas Verdes (AV) & Borreguil (BG) & Mosca (MC) & Cuadrada (CD) \\
\hline Latitude & $37^{\circ} 03^{\prime} 07.63^{\prime \prime} \mathrm{N}$ & $37^{\circ} 03^{\prime} 06.69^{\prime \prime} \mathrm{N}$ & $37^{\circ} 02^{\prime} 54.79^{\prime \prime} \mathrm{N}$ & $37^{\circ} 03^{\prime} 09.53^{\prime \prime} \mathrm{N}$ & $37^{\circ} 03^{\prime} 35.03^{\prime \prime} \mathrm{N}$ & $37^{\circ} 01^{\prime} 37.18^{\prime \prime} \mathrm{N}$ \\
\hline Altitude (m asl) & 3,020 & 3,040 & 3,050 & 2,980 & 2,920 & 2,840 \\
\hline Lake area (ha) ${ }^{\mathrm{a}}$ & 0.42 & 0.07 & 0.19 & 0.18 & 0.44 & 0.24 \\
\hline Maximum depth $(\mathrm{m})$ & 2.9 & 2.6 & 2.8 & 2.0 & 2.8 & 4.8 \\
\hline Maximum volume $\left(\mathrm{m}^{3}\right)^{\mathrm{b}}$ & 4,772 & 447 & 1,262 & 2,070 & 7,044 & - \\
\hline Catchment area/surface area ${ }^{a}$ & 21.5 & 78.3 & 67.4 & 282.8 & 82.7 & 16.7 \\
\hline $\mathrm{pH}$ & $6.0-7.6(6.9)$ & $6.4-7.8(7.2)$ & $6.2-7.2(6.7)$ & 6.3 & $7.5-7.8(7.7)$ & 7.7 \\
\hline Conductivity $(\mu \mathrm{S} / \mathrm{cm})$ & $10-77(24)$ & 14-17 (15) & $25-30(27)$ & 13-15 (14) & $27-37(32)$ & $6-9(7)$ \\
\hline Chl- $a(\mu \mathrm{g} / \mathrm{L})$ & $0.3-1.1(0.6)$ & $0.6-2.1(1.2)$ & $0.6-1.1(0.8)$ & $1.4-1.7(1.5)$ & $0.04-2.1(1.1)$ & $0.5-1.8(1.1)$ \\
\hline $\mathrm{DOC}(\mathrm{mg} / \mathrm{L})$ & $0.7-2.7$ (1.8) & $0.9-1.3(1.1)$ & 0.7-1.2 (0.9) & $0.6-1.1(0.9)$ & $1.1-1.4(1.2)$ & $0.3-1.3(0.7)$ \\
\hline Calcium (mg/L) & $0.5-2.1(1.2)$ & $0.5-2.8(1.9)$ & $1.9-2.1(2.0)$ & $0.8-1.1(1.0)$ & $3.0-6.6(5.0)$ & $0.3-1.1(0.6)$ \\
\hline
\end{tabular}

TP, total phosphorus; TN, total nitrogen; Chl- $a$, chlorophyll- $a$; DOC, dissolved organic carbon.

Range and mean values or single values of the chemical and biological parameters from water column measurements are shown. Chemical and biological characteristics are from Sánchez-Castillo, Cruz-Pizarro, and Carrillo (1989), Morales-Baquero et al. (1999), Reche et al. (2005) as well as from water column samples taken during each core sampling day and for punctual subsequent samples. Data are derived from a monitoring study over the past 10 years in RS lake and for punctual samplings in RSS, AV, BG, MC, and CD lakes. Range and mean values (in brackets) are from a minimum of four samples for RSS and AV, three for BG, two for MC and CD.

${ }^{\text {aD }}$ ata from Morales-Baquero et al. (1999).

${ }^{\mathrm{b}}$ Data from Egmasa S.A.

(PEARL), Queen's University, Kingston ON, Canada using the same methodology.

\section{4 | Climate data}

Long-term climate records do not exist for Sierra Nevada summits, but short series of homogenized mean annual temperature records dating back to 1960 are available from meteorological stations (Armilla and Lanjarón, http://www.aemet.es) located at lower altitudes that are less than $20 \mathrm{~km}$ from the Sierra Nevada summits. A comparison between these short series of temperature data with longer homogenized air temperature records from Central and South Spain (Staudt, Esteban-Parra, \& Castro-Díez, 2007) determined they were most strongly correlated with the Madrid climate station (AEMET 3195; Armilla $r=.72, \quad p<.001, n=51$ and Lanjarón $r=.78, p<.001, n=54$ ), and that this long-term annual temperature series from Madrid (dating back to 1869) is representative of the Sierra Nevada region. As there are also no long-term records of precipitation from the Sierra Nevada summits, we compared the homogenized short series of precipitation from Armilla (dating back to 1940) with five long series from the south of Spain. The strongest correlation was with the San Fernando series (Naval Base of the Spanish Army, Cádiz, since 1839; $r=.62, p<.001, n=65$ ), which was then used as representative of precipitation trends in the Sierra
Nevada region, due to the similarity of precipitation patterns across Southern Spain (Esteban-Parra, Rodrigo, \& Castro-Díez, 1998). Thus, we use MAAT Madrid (mean annual air temperature series from Madrid station) and AP San Fernando (annual precipitation series from San Fernando station) as representatives of air temperature and precipitation tendencies of the Sierra Nevada region throughout the analyses.

\section{5 | Chlorophyll-a}

For each core, sedimentary chlorophyll-a concentrations were inferred with visible reflectance spectroscopy using a FOSS NIRSystems Model 6500 series Rapid Content Analyzer (Tidestone Technologies Inc.) to measure spectral reflectance of sediments that had been freeze-dried and sieved through a $125 \mu \mathrm{m}$ mesh, following the methods described by Michelutti, Wolfe, Vinebrooke, Rivard, and Briner (2005) and Michelutti et al. (2010). Importantly, the chlorophyll- $a$ reconstructions include chlorophyll- $a$ as well as all chlorophyll isomers and its major derivatives (pheophytin and pheophorbide), and therefore accounts for the major diagenetic products (Michelutti \& Smol, 2016; Michelutti et al., 2010).

Due to the presence of algal mat material in the uppermost sedimentary interval from each lake $(0-0.5 \mathrm{~cm}$ for RS and $0-0.25$ for the other five lakes), these intervals were excluded from the chlorophyll- 
$a$ analyses, as they could not be reliably identified as exclusively representing sedimentary chlorophyll-a.

\section{6 | Subfossil Cladocera}

Subfossil cladoceran samples were analyzed and identified using the methods described in Szeroczyńska and Sarmaja-Korjonen (2007). For each sediment core interval, $\sim 1 \mathrm{~cm}^{3}$ of fresh sediment was heated for $20 \mathrm{~min}$ in $10 \% \mathrm{KOH}$ to remove humic matter and then washed and sieved through a $38 \mu \mathrm{m}$ mesh under tap water. The samples were centrifuged ( $5 \mathrm{~min}, 1,207.44 \mathrm{~g}$ ) to concentrate the fossil cladoceran remains, and mounted onto microscope slides using glycerol gelatin dyed with safranin. A minimum of 200 remains (carapaces, headshields, postabdomens, postabdominal claws, valves, shells, and ephippia) were identified and enumerated from each sediment interval under a light microscope at $200 \times$ magnification (Kurek, Korosi, Jeziorski, \& Smol, 2010). The most abundant remain from each taxon was used to calculate the number of individuals present in the sample (Frey, 1986). For Daphnia taxa, the abundance of individuals was principally determined from ephippia and postabdominal claws, as these were the only remains encountered in most samples. Due to the difficulties associated with identifying individual daphniid remains to the species level, daphniid taxa were grouped as Daphnia pulex gr. (represented by Daphnia pulicaria in RSS, RS, and CD, and Daphnia pulex in BG). The presence of two species of Daphnia (D. pulicaria and D. pulex) from the D. pulex species complex was determined in another study through genetic analyses of daphniid ephippial eggs in Sierra Nevada lakes from the last 60 years (J.M. Conde-Porcuna, J. Veiga-Neto, C. Pérez-Martínez, L. Jiménez, E. Ramos-Rodréguez, E. Moreno, unpublished data).

Counts of individual cladocerans are presented as relative abundances and all the cladoceran taxa from each site are included in the stratigraphic plots. Biostratigraphic zones based on the cladoceran sedimentary assemblages over time were identified through cluster analysis using constrained incremental sum of squares (CONISS), on square root transformed relative abundance data with chord distance as the dissimilarity coefficient using the program Tiliagraph View (TGView), version 2.02 (Grimm, 2004), zones were determined via the broken stick model (Bennett, 1996).

\subsection{Saharan dust deposition data and drivers}

To determine whether past Daphnia populations may be linked to Saharan atmospheric dust input, we inferred past trends in Ca deposition using a selection of proxies. First, we measured the zirconium aluminum ( $\mathrm{Zr} / \mathrm{Al})$ ratio in sediment core intervals from one of our study lakes (RS) to represent dust deposition for this region. This approach was chosen because Saharan dust is rich in $\mathrm{Zr}$ (Guieu \& Thomas, 1996) and this ratio has been successfully used as a proxy of Saharan input in the Mediterranean and other areas (e.g., Jiménez-Espejo et al., 2007; Wehausen \& Brumsack, 1999). Saharan deposition has been demonstrated to be synchronous among three sites (intersite distance of $40 \mathrm{~km}$ ) close to the Sierra Nevada
(Morales-Baquero \& Pérez-Martínez, 2016), thus the temporal trends in the $\mathrm{Zr} / \mathrm{Al}$ ratio measured in one of our lakes must be the same for the rest of the study lakes. Al was measured by atomic absorption spectrometry (AAS) using a PerkinElmer 5100 spectrometer and $\mathrm{Zr}$ was performed using inductively coupled plasma-mass spectrometry (ICP-MS) after digestion in $\mathrm{HNO}_{3}(65 \%)+\mathrm{HF}(48 \%)$ of $0.1 \mathrm{~g}$ of sample powder in a Teflon-lined vessel for $150 \mathrm{~min}$ at high pressure and temperature, evaporated to dryness, and subsequent dissolved in $100 \mathrm{ml}$ of 4 vol.\% HNO3. Instrumental measurements were carried out in triplicate with a NexION 300d (PerkinElmer) spectrometer. We then used ice core data obtained from the French Alps glacier (Col du Dôme glacier) by Preunkert and Legrand (2013), who chemically identified Saharan dust events and quantified the Ca concentrations from 1906 to 2004 (with an 18-year gap between 1953 and 1970 due to a hiatus in the core; Preunkert \& Legrand, 2013; Figure 4). We used the raw summer Ca data from a well-dated part of one of the Preunkert and Legrand (2013) cores. Collectively, the available literature on Saharan aerosols indicates that a significant amount of African dust is transported to the Mediterranean region annually (especially in spring and summer), with Saharan annual dust deposition higher in southern Mediterranean areas than at more northern sites (reviewed in Pey et al., 2013). Hence, Saharan dust deposition in Sierra Nevada is likely higher than in the French Alps, although the long-term trend of Saharan dust deposition should be similar in both regions.

Within Europe, Sierra Nevada summits are ideally situated to receive a high concentration of atmospheric dust deposition due to their proximity to the Sahara $(70 \%$ of Saharan dust is deposited within 2,000 km), high altitude (Saharan dust circulates between 1,500 and 4,000 $\mathrm{m}$ asl), and because they are in the path of the Saharan dust particles' movement toward the western Mediterranean (Morales-Baquero et al., 2013; Pey et al., 2013). As the Sierra Nevada lakes have naturally low $\mathrm{P}$ and $\mathrm{Ca}$ concentrations (Table 1 ), we expect changes in the deposition of dust laden with $\mathrm{P}$ and $\mathrm{Ca}$ to affect primary production and local biota, especially Ca-rich cladoceran species. To test this hypothesis, we compared the sedimentary $\mathrm{Zr} / \mathrm{Al}$ ratios and the $\mathrm{Ca}$ concentration record derived from the Alps ice core with our paleolimnological cladoceran records. However, the $\mathrm{Zr} / \mathrm{Al}$ ratio is only usable for RS sediment intervals and the available ice core Ca record has an 18 year gap and is shorter than the paleolimnological cladoceran records. For this reason, to make comparisons with our cladoceran assemblage trends, we used the wNAO (winter North Atlantic Oscillation) index and the Sahel precipitation index records (both series longer than ice core Ca record) as representatives of Saharan and Ca deposition tendencies in Sierra Nevada because the intensity of Saharan dust emission and transport has been linked to wNAO (Moulin, Lambert, Dulac, \& Dayan, 1997) and more recently to the Sahel drought (Chiapello, Moulin, \& Prospero, 2005; Moulin \& Chiapello, 2004). The wNAO index (DJFM) defined by Hurrell (1995) is based on the difference of normalized sea level pressure between the Azores High (Lisbon, Portugal) and the Iceland Low (Stykkisholmur, Iceland) stations. Hurrell's wNAO index dataset extends back to 1864 on a monthly mean basis (http://climatedata 
guide.ucar.edu/guidance/hurrell-north-atlantic-oscillation-nao-indexstation-based). The Sahel precipitation index (SPI), extending back to 1900, provided by the University of Washington and the Joint Institute for the Study of the Atmosphere and Ocean (http://jisao.wash ington.edu/data/sahel/), provided a standardized rainfall index data for the Sahelian zone of northern Africa. The stations are situated within 20-10N, 20W-10E, and the dataset was obtained from the NOAA Global Historical Climatology Network.

\subsection{Statistical analyses}

Relationships between climate and dust metrics (MAAT Madrid, AP San Fernando, the ice core Ca record, $\mathrm{Zr} / \mathrm{Al}$ ratio, the wNAO index and the SPI) and between these metrics and sedimentary proxies (individual cladoceran taxa for species-scale trends, chlorophyll- $a$ concentrations for trends in primary production) were examined for each study lake using Pearson's correlation analysis, after assessing each variable for normality using the Kolmogorov-Smirnov test. Cladoceran relative abundance data were square root transformed prior to the analyses, and the annually resolved climate and dust metrics were averaged over the period of accumulation for each dated interval, thereby integrating the instrumental data with the paleolimnological data (Sorvari, Korhola, \& Thompson, 2002). To correct for possible trends in the variables and avoid spurious correlations, we follow the procedure used by Gerten and Adrian (2000) whereby the Mann-Kendall trend test (PAST software; Hammer, Harper, \& Ryan, 2001) was applied to each correlating variable to detect trends over time. Those variables for which the Mann-Kendall test indicated a significant linear trend were detrended by fitting a linear regression versus time and the residuals were then used for the subsequent correlation analysis. Breakpoint analyses using a two-segment piecewise linear regression were applied to MAAT Madrid and AP San Fernando series data to estimate the timing of largest change in each series.

To explore potential drivers of chlorophyll-a, model selection analyses (Burnham \& Anderson, 2002) were performed with climate and atmospheric variables as independent variables. To identify the explanatory variables of cladoceran assemblage changes, two complementary techniques were chosen: (i) model selection analyses with chlorophyll-a, climate, and atmospheric variables as independent variables and axis 1 scores of the principal component analysis (PCA) of cladoceran assemblages as the dependent variable; and (ii) redundancy analysis (RDA) with the same explanatory variables for the entire cladoceran assemblages. The PCA axis 1 scores summarize the main variation in cladoceran assemblage and therefore the results of the regression indicate the drivers of the main shift in Cladocera, while the RDA explores the drivers of changes among the entire cladoceran assemblages. The RDA (with forward/backward selection) was performed to identify the statistical independence and relative strength of each of the explanatory variables of the cladoceran assemblage changes, using Monte Carlo permutation tests (999 unrestricted permutations) with a significance level of $p<.05$. Finally, model selection analyses with chlorophyll- $a$, climate, and atmospheric variables as independent variables were performed to explore the explanatory variables of Daphnia changes. To normalize the variance, explanatory variables were $z$-score transformed prior to the analyses. Ordination and model selection analyses were performed using the vegan (Oksanen et al., 2015) and the MuMIn (Multi-Model Inference; Bartoń, 2014) packages for the R software environment ( $R$ Development Core Team, 2015), respectively. Akaike's information criterion adjusted for sample size (AICc; Burnham \& Anderson, 2002) was used to select the optimum model. Models with a difference of $\triangle \mathrm{AICc}<2$ compared to the lowest $\mathrm{AICc}$ were considered the best models and statistically equivalent. The significance and the percentage of variance explained for each variable was determined to define the contribution to the final model. Residuals of the final models were examined to check for normality of data and absence of over-dispersion. To avoid spurious relationships in multiple regression results, multicollinearity among the explanatory variables were explored by analyzing the variance inflation factors (VIFs). All the explanatory variables yielded VIFs $<5$ and therefore were kept in the analysis due to the low degree of collinearity.

\section{3 | RESULTS}

\subsection{Sediment chronology}

The total ${ }^{210} \mathrm{~Pb}$ activity profiles for most cores (RS, AV, MC and BG) exhibited a characteristic exponential decline with sediment depth, while in RSS and CD the decline was more gradual. The supported ${ }^{210} \mathrm{~Pb}$ levels (background) were reached between 7 and $13 \mathrm{~cm}$ in all cores (Figure 2). Clear peaks in ${ }^{137} \mathrm{Cs}$ activity were observed in four of the sediment cores, while the peaks observed in RSS and CD were less distinct (Figure 2), but still correspond to an estimated ${ }^{210} \mathrm{~Pb}$ age of $1960-1970$, consistent with the 1963 peak in atmospheric radioisotopic fallout (Figure 2). The average sediment accumulation rate for the past 50 years ranged from 0.01 to $0.03 \mathrm{~g} \mathrm{~cm}^{-2}$ year $^{-1}$, which is common in alpine lakes situated above tree line where sedimentation rates are typically low (Saros, Interlandi, Wolfe, \& Engstrom, 2003). The temporal resolution of the sediment cores ranged between 2 and 5 years per interval for the past 50 years (at $0.25 \mathrm{~cm}$ intervals for all the lakes, except for RS at $0.5 \mathrm{~cm}$ intervals).

\section{2 | Climate data}

Mean annual air temperature (MAAT) from the Madrid climate station (1869-2011) indicates a warming trend began at the turn of the 20th century (Figure 3). Over the 143-year record, MAAT increased by $1.76^{\circ} \mathrm{C}$, and a two-segment, piecewise linear regression applied to the MAAT Madrid series identified a threshold change to significantly higher mean temperatures in the early 1970s (breakpoint $=1972 \pm 4.7$ years, $p<.0001$ ). The temperature increased by $0.52^{\circ} \mathrm{C}$ (i.e., the slope of a linear regression over the time period) over the period 1869 to 1972 and by $1.68^{\circ} \mathrm{C}$ over the period 1972 

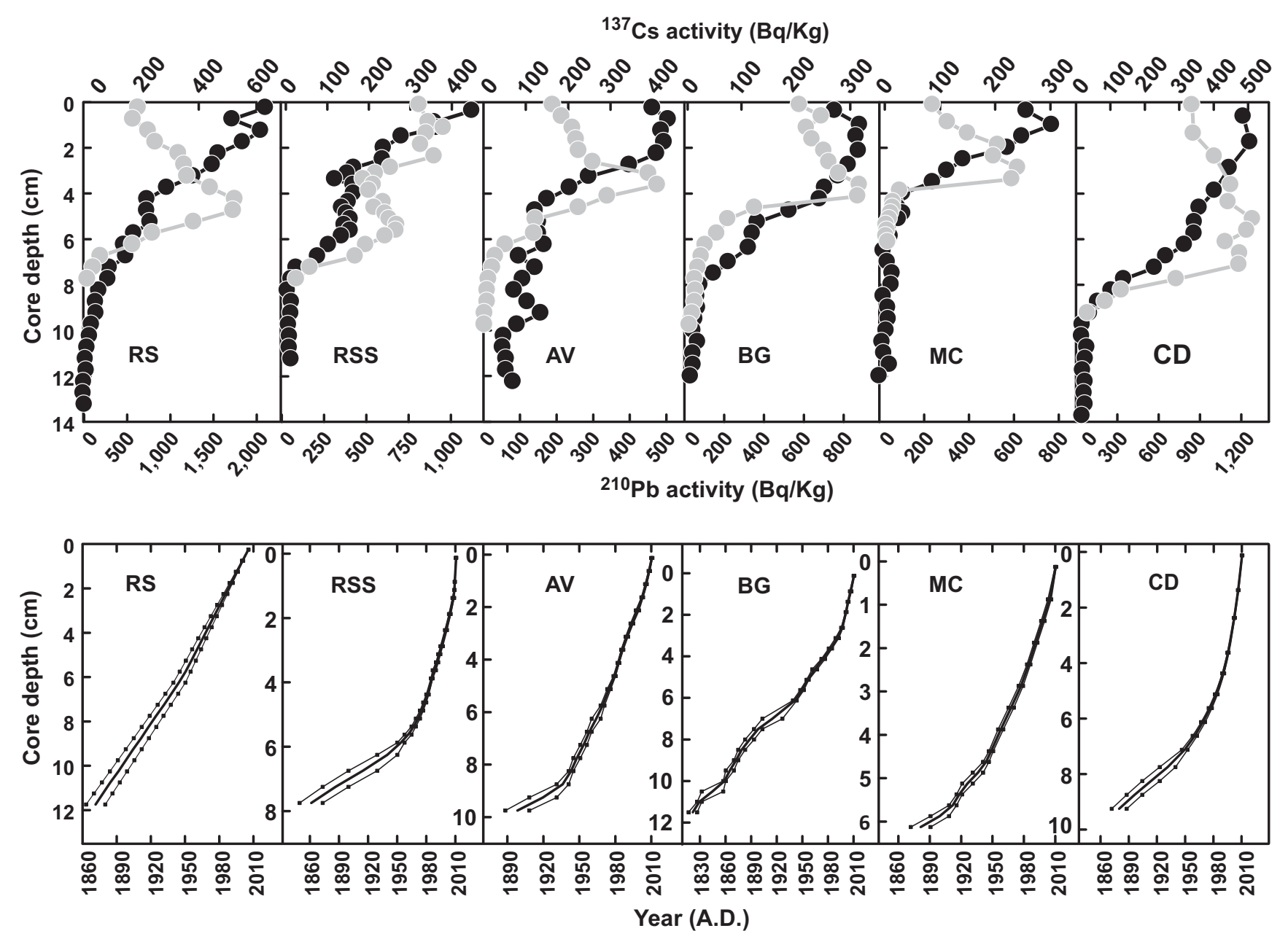

FIGURE 2 Radiometric chronology showing ${ }^{210} \mathrm{~Pb}$ (black circle) and ${ }^{137} \mathrm{Cs}$ (gray circle) activity (bq/kg dried sediment) for the six study lakes in the Sierra Nevada region. The lower panels depict ${ }^{210} \mathrm{~Pb}$-estimated age (using the constant rate of supply model) versus core depth (solid lines) and the associated errors (solid squares)

to 2011. Total annual precipitation (AP) from the San Fernando climate station indicates that the second half of the 19th century was wetter than the rest of the precipitation series, reaching a maximum around 1860-1870 and then decreasing from the late 19th century to the present, interrupted only by positive anomalies in the 1960s (Figure 3). The last 40 years of the AP San Fernando record exhibit persistent low precipitation values that were particularly low from 1985 to 1995 . No significant breakpoint was identified by piecewise linear regression on the precipitation data.

\section{3 | Sedimentary chlorophyll-a}

All six lakes have experienced notable increases in sedimentary chlorophyll-a concentrations beginning between 1960 and $\sim 1970$ that are especially prominent since the 1990 s (Figure 4). For each lake, strong and significant correlations exist (all $r>.40, p<.05$ ) between chlorophyll- $a$ trends and the MAAT Madrid trends (variables detrended when needed), after integrating air temperature to the period represented for each dated interval (sensu Sorvari et al., 2002). Chlorophyll-a is also significantly correlated with SPI in RS,
AV, and BG $(p<.05)$ and with AP San Fernando in RSS $(p<.05)$. Model selection analyses indicate that air temperature is the main driver of chlorophyll- $a$ in all the lakes with SPI and AP San Fernando as secondary drivers in some of the lakes (Table 2).

\section{4 | Subfossil cladocera}

The paleolimnological cladoceran records share similarities in timing and direction in taxon-specific changes across all of the Sierra Nevada study lakes (Figures 5 and 6). The most striking cladoceran assemblage shift within the past $\sim 150$ years is the decline in relative abundance of Chydorus sphaericus and the concurrent increase in Alona quadrangularis (or Daphnia pulex gr. in CD; Figure 5). In three of the lakes (MC, RS, and RSS), A. quadrangularis is either a new arrival or was present in only trace abundances in the deeper sedimentary intervals. With the exception of $\mathrm{AV}$, this taxon-specific cladoceran change started gradually at the turn of the century, but was most striking in all lakes post-1980s, as highlighted by PCA zscores (Figure 6). Biostratigraphic zones of change in the cladoceran records were identified by the broken stick model at 1990 in RS, 


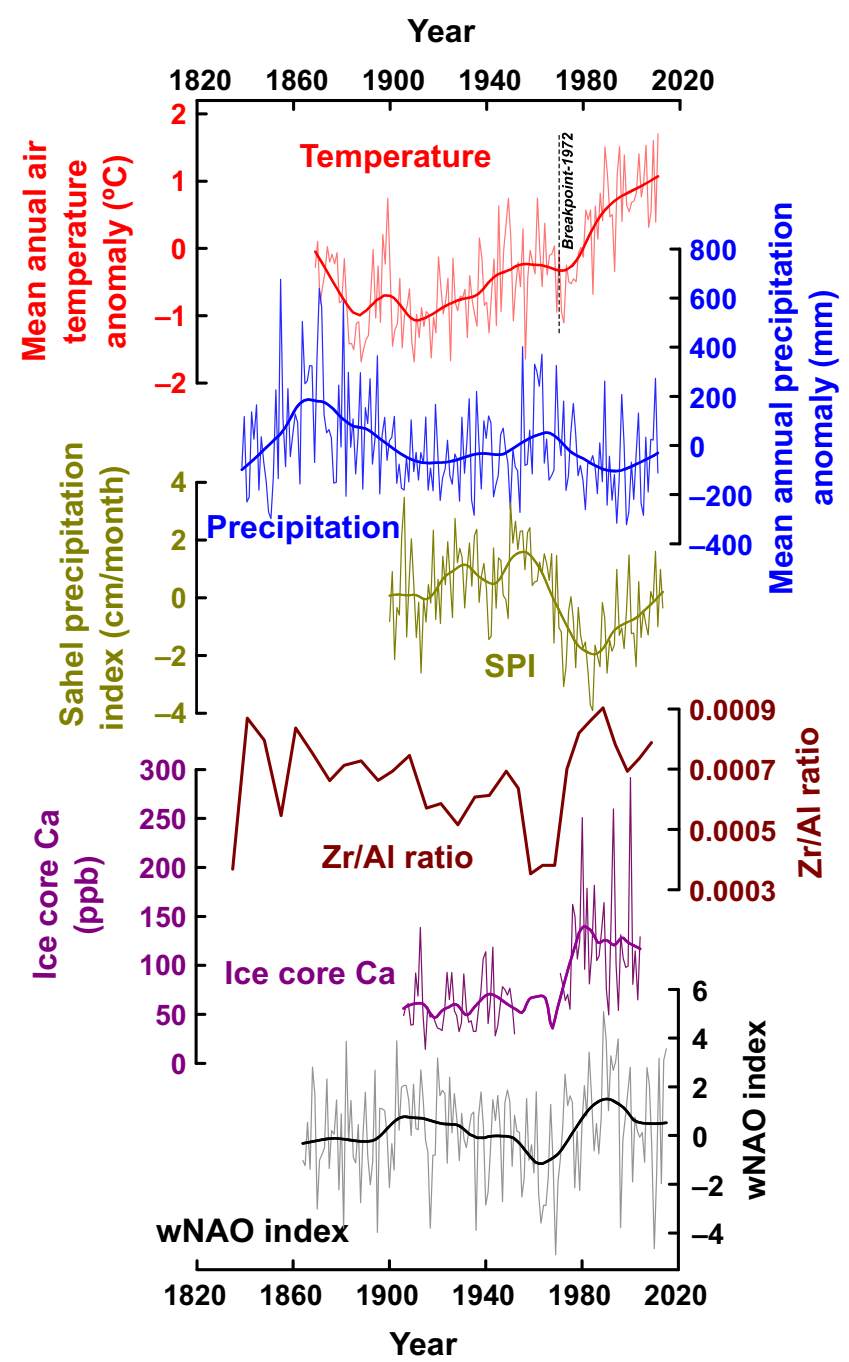

FIGURE 3 A comparison of historical trends including the mean annual air temperature anomaly from Madrid climate station (MAAT Madrid), the annual precipitation anomaly from San Fernando climate station (AP San Fernando) since 1860 and 1840, respectively, the WNAO index, the Sahel precipitation index (SPI), the Saharan calcium values ( $\mathrm{ppb}$ ) from an ice core from the Col du Dôme glacier of the French Alps (Preunkert \& Legrand, 2013), and the $\mathrm{Zr} / \mathrm{Al}$ ratio (proxy for regional Ca inputs) from the RS sediment core. Temperature anomalies are calculated from the period 1961 to 1990 and precipitation anomalies are calculated over the entire period. The anomalies of the SPI are calculated with respect to 1900 and 2013, and based on June through October averages for each year. A LOESS smoother ( $s p a n=0.2$ ) was applied to all the variables to improve the clarity of the figure and highlight trends. The breakpoint identified by a two-segment piecewise linear regression in the temperature series data are represented by a dashed line [Colour figure can be viewed at wileyonlinelibrary.com]

RSS, BG, and MC, 2000 in CD, whereas no important zonation was identified in AV (Figure 5).

Changes in the cladoceran sedimentary assemblages coincide with trends in the MAAT Madrid and AP San Fernando data (Figures 3 and 6). Increases in air temperature and relatively low precipitation values following the wet period at the end of the 19th

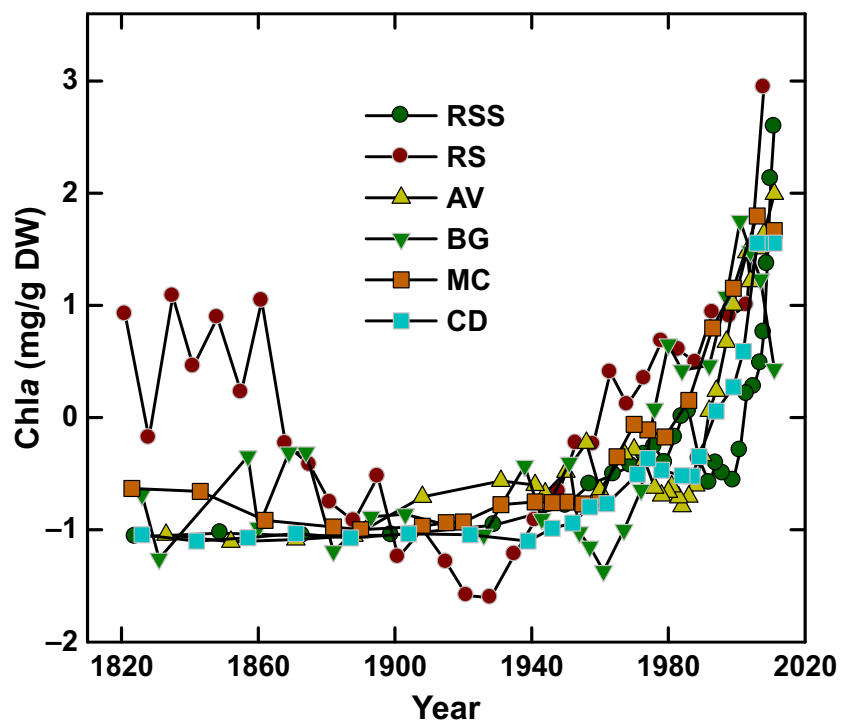

FIGURE 4 Concentration of sedimentary chlorophyll- $a$ and derivatives (standardized to mean variance using z-scores) for the six study lakes. Lake name abbreviations: Río Seco (RS), Río Seco Superior (RSS), Aguas Verdes (AV), Borreguil (BG), Mosca (MC) and Cuadrada (CD) [Colour figure can be viewed at wileyonlinelibrary.com]

century are concurrent with subtle changes in the cladoceran record. The highest air temperatures on record occurred during a period of low precipitation post-1980 that was accompanied by the most pronounced cladoceran changes in the study lakes (Figures 3 and 6). Increased primary production was observed after the 1970s in all lakes and is consistent with increased temperatures and with the period of maximum Saharan dust deposition (Figures 3 and 4), delivering P-rich dust to the lakes. Daphnia pulex gr. was observed in four of the six study lakes (RS, RSS, BG, and CD) with relative abundances that were generally greatest in the recent sediments (Figure 5), although the magnitude of this increase varies among lakes (Figure 7). For example, a striking increase in Daphnia has occurred in RS since the early 1970s, while in CD increases in Daphnia abundance follow a gradual increase since the early 1900s that is particularly pronounced after 1980 . In RSS, Daphnia occurs in low relative abundance and exhibits minimal changes with a slight increase since 2000 (Figures 5 and 7). In BG, D. pulex gr. is represented by only a few sedimentary ephippia and postabdominal claws over the last 50 years.

\subsection{Saharan dust deposition data and drivers}

The $\mathrm{Zr} / \mathrm{Al}$ ratio from RS and the Ca record derived from the Alps ice core (adapted to RS intervals) show a highly significant correlation $\left(r=.785, p=8.8 \times 10^{-4}\right)$. Both variables were considerably higher in the past $\sim 50$ years than in the early 20th century (Figure 3 ), coinciding with the observed changes in SPI and the wNAO index, that, respectively, experienced their lowest and highest values in recent decades. As both indices control Saharan dust emission and 


\begin{tabular}{|c|c|c|c|c|c|}
\hline & Response variable & Regression model & Adj $R^{2}$ & $F$ & $\mathrm{AICc}$ \\
\hline \multicolumn{6}{|c|}{ RS lake } \\
\hline 1 & Chl- $a$ & $-0.25+0.74^{* * *}$ Temp & 0.624 & 37.6 & 30.5 \\
\hline \multicolumn{6}{|c|}{ RSS lake } \\
\hline 1 & Chl- $a$ & $0.09+0.64^{* * *}$ Temp $-0.13^{\S} \mathrm{SPI}$ & 0.772 & 36.5 & 23.9 \\
\hline 2 & & $0.14+0.63^{* * *}$ Temp & 0.701 & 54.6 & 25.4 \\
\hline \multicolumn{6}{|c|}{ AV lake } \\
\hline 1 & Chl- $a$ & $0.04+0.65^{* * *}$ Temp & 0.520 & 30.3 & 55.9 \\
\hline \multicolumn{6}{|c|}{ BG lake } \\
\hline 1 & Chl- $a$ & $\begin{array}{l}0.03+0.53^{* *} \text { Temp }- \\
0.29^{*} \mathrm{SPI}-0.45^{*} \text { Precip }\end{array}$ & 0.840 & 30.6 & 32.2 \\
\hline \multicolumn{6}{|c|}{ MC lake } \\
\hline 1 & Chl- $a$ & $-0.08+0.83^{* * *}$ Temp $-0.17^{\S} \mathrm{SPI}$ & 0.808 & 32.5 & 26.5 \\
\hline 2 & & $0.05+0.89^{* * *}$ Temp & 0.745 & 53.6 & 26.9 \\
\hline \multicolumn{6}{|c|}{ CD lake } \\
\hline 1 & Chl- $a$ & $0.03+0.74^{* *}$ Temp & 0.708 & 44.6 & 29.7 \\
\hline 2 & & $-0.03+0.72^{* *}$ Temp $-0.12^{\text {ns }} S P I$ & 0.682 & 17.1 & 31.5 \\
\hline
\end{tabular}

TABLE 2 Results of the Akaike's information criterion (AICC) values identifying the best models for predicting sedimentary chlorophyll- $a$ for the six study lakes

Temp, Madrid air temperature; Precip, San Fernando precipitation; SPI, Sahel precipitation index; wNAO, winter NAO index.

Explanatory variables were standardized to mean variance using $z$-scores prior to analyses. Adj $R^{2}$, adjusted $R^{2}$.

Significant level: ${ }^{* * *} p<.001 ; * * .001<p<.01 ; * .01<p<.05 ;{ }^{\S} .05<p<.1 ;{ }^{\text {ns }} p>.1$.

transport, we can consider them to be predictors of the transport and intensity of Saharan dust events in Sierra Nevada and representative of $\mathrm{P}$ and $\mathrm{Ca}$ deposition trends in Sierra Nevada. The significant correlations found between $\mathrm{Zr} / \mathrm{Al}$ ratio and both indices (SPI: $r=-.862, p=2.0 \times 10^{-6} ;$ wNAO: $\left.r=.361, p=.049\right)$ and between the $\mathrm{Ca}$ ice core and SPI $\left(r=-.448, p=2.8 \times 10^{-5}\right)$ support this assumption. The wNAO index was consistently high (positive index values) from the mid-1970s onward, reaching a maximum during the 1980-1990s (Figure 3). A predominantly wet period (positive values) in the SPI record occurred from 1900 to $\sim 1970$, followed by a relatively stable and dry period (negative values) from $\sim 1970$ to the 1980 s onward, with the lowest values observed during the 1980 s1990s (Figure 3).

Both the wNAO index versus the AP San Fernando and the WNAO index versus the SPI are negatively correlated $(r=-.454$, $p=4 \times 10^{-10}$ and $r=-.250, p=.007$, respectively), as are the SPI and the MAAT Madrid $(r=-.278, p=.003)$.

\subsection{Relationships between proxy data and instrumental records}

Results of the RDA indicate temperature to be the main driver of the cladoceran sedimentary assemblages for all the lakes except MC and $C D$, where chlorophyll- $a$ is the main explanatory variable (Table 3). SPI is a secondary explanatory variable in some of the lakes. The percentage of explained variance ranged from $11 \%$ in $C D$ to $53 \%$ in $\mathrm{MC}$.

PCA axis 1 sample scores explained 38\% (RS), 75\% (RSS), 99\% $(\mathrm{AV}), 66 \%(\mathrm{BG}), 53 \%(\mathrm{MC})$, and $69 \%(\mathrm{CD})$ of the variance of the cladoceran assemblage data, while PCA axis 2 sample scores explained $<29 \%$ in all the lakes.

PCA axis 1 sample scores track the main cladoceran assemblage changes, particularly the replacement of $C$. sphaericus by either A. quadrangularis or $D$. pulex gr. The model selection analyses indicate temperature and/or chlorophyll- $a$ to be the main predictor variables of PCA axis 1 sample scores for all the study lakes (Table 3), with the amount of variance explained by these variables ranging from $34 \%$ in CD to $88 \%$ in MC. Secondary explanatory variables in all of the lakes are SPI and wNAO.

The timing of the main changes of D. pulex gr. were generally coherent with climate metrics (MAAT Madrid and AP San Fernando) and chlorophyll-a changes (Figures 3, 4 and 7). The period of Daphnia increase in RS, BG, and CD is also concurrent with the period of maximum $\mathrm{Ca}$ deposition, and the timing of maximum change in the wNAO index and SPI (Figure 7). Daphnia relative abundances are significantly and negatively correlated with the SPI record in RS and CD $(r>-.45, p<.01)$ and marginally significant in RSS ( $r=-.42, p=.057)$. Moreover, Daphnia is significantly and positively correlated with chlorophyll- $a(r=.38$, $p=.036)$ and wNAO index in RS $(r=.68, p=.001)$. A marginally significant correlation between Daphnia and MAAT Madrid was found in RS ( $r=.40, p=.058$ ) and with AP San Fernando in CD $(r=-.29, p=.081)$. Model selection analyses indicate that the main predictor variables of $D$. pulex gr. in RS is the SPI, with WNAO index and AP San Fernando as secondary explanatory variables (all models explained $\sim 60 \%$ of the observed variation) and chlorophyll- $a$ in RSS and CD with more than $20 \%$ of explained variance (Table 4). 

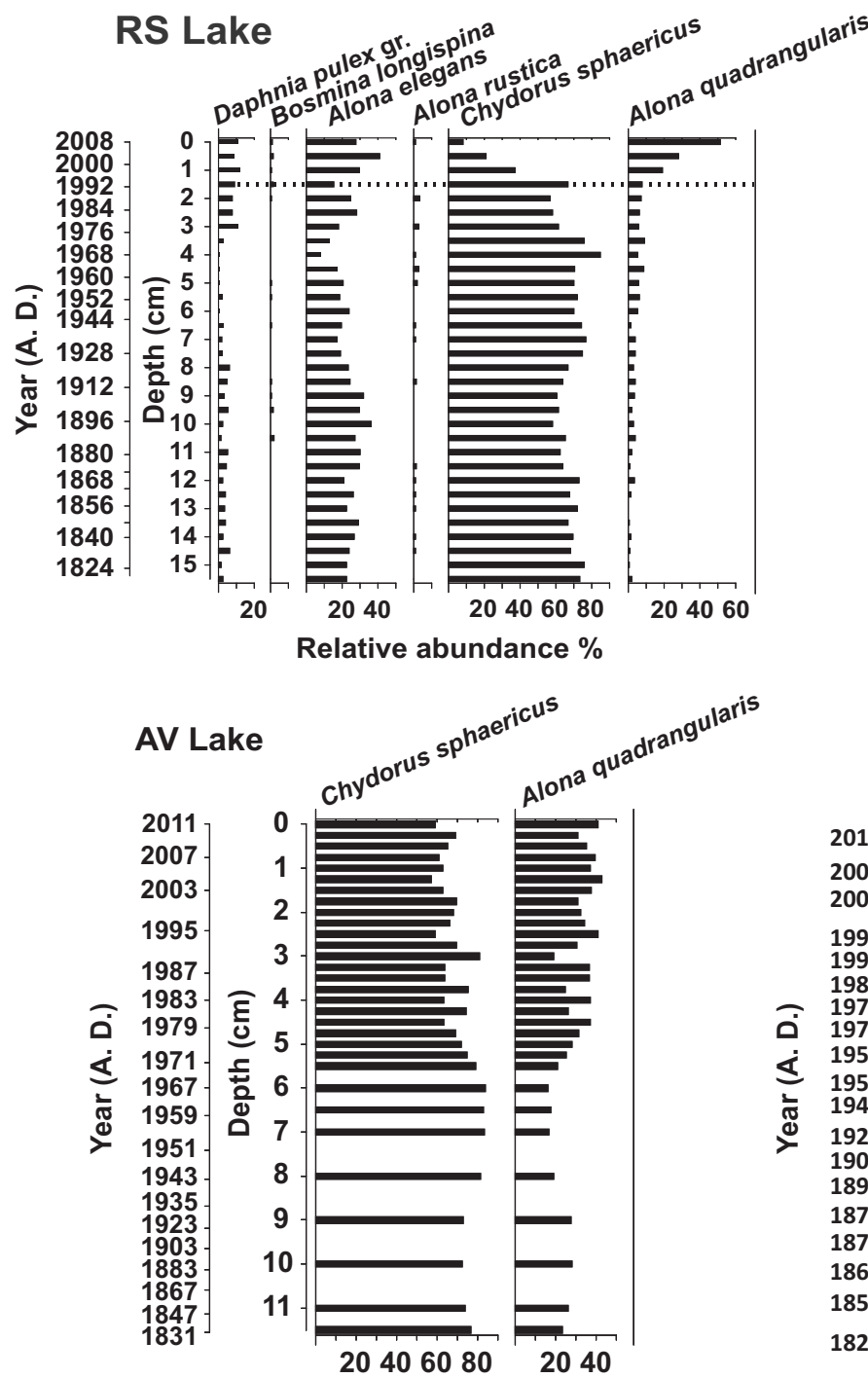

Relative abundance \%

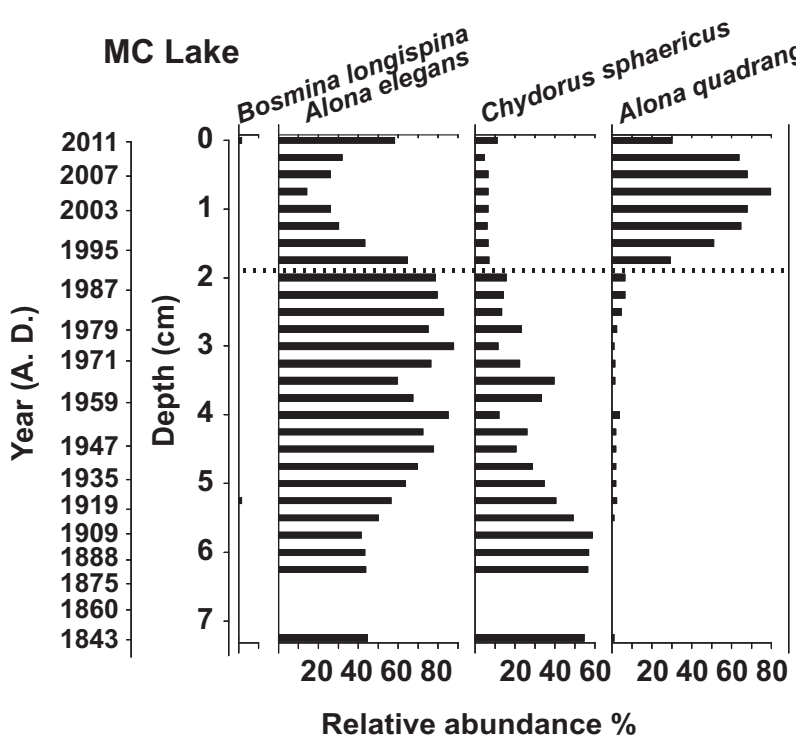

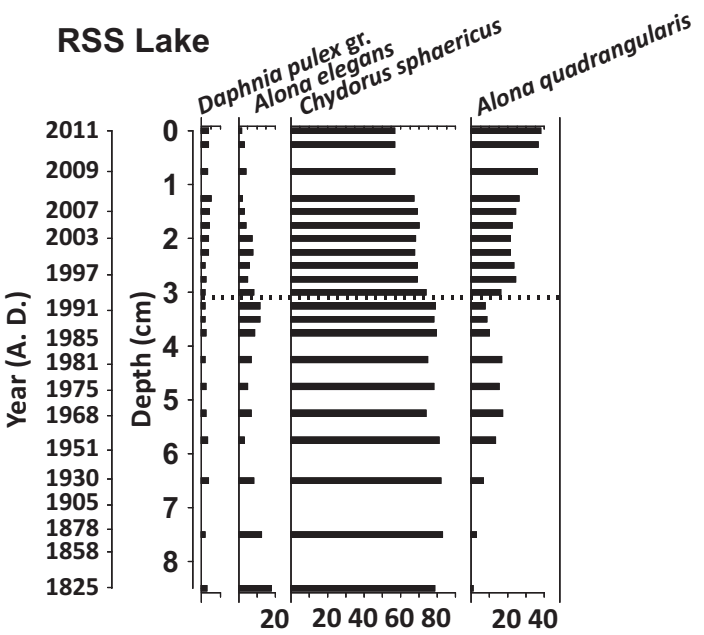

Relative abundance \%

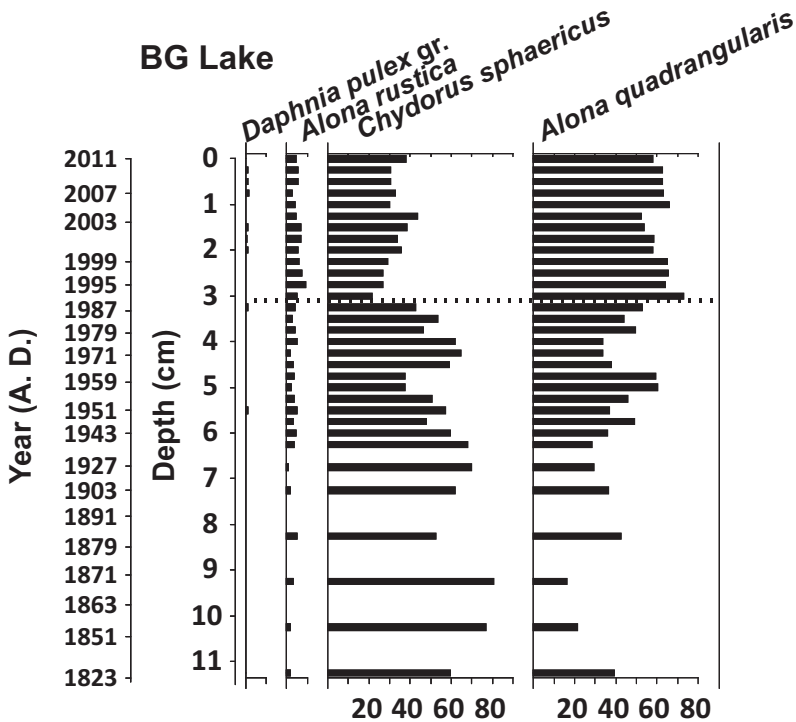

Relative abundance \%

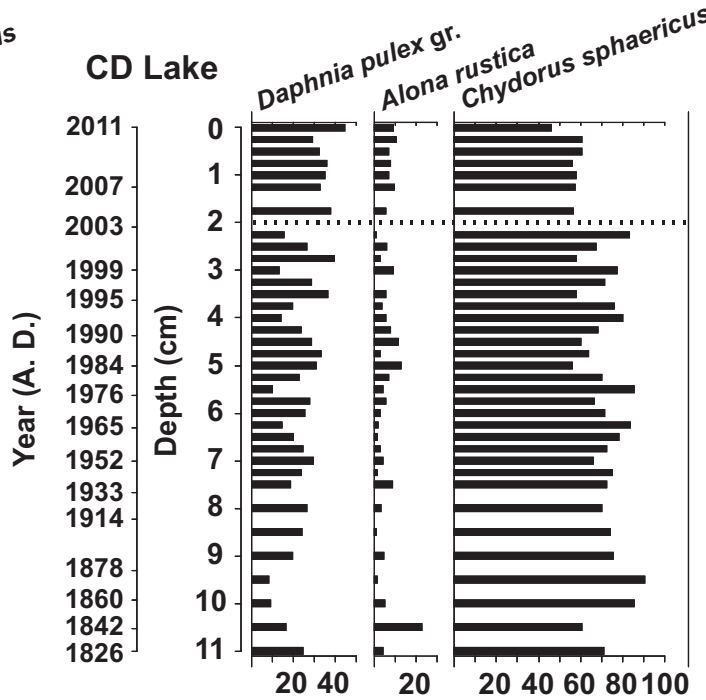

Relative abundance \%

FIGURE 5 Relative frequency diagrams of the most common cladoceran taxa recorded in the sediment cores from the six study lakes. The broken line represents the main zonation identified by the broken stick model. Dates prior to 1850 should be interpreted with caution 


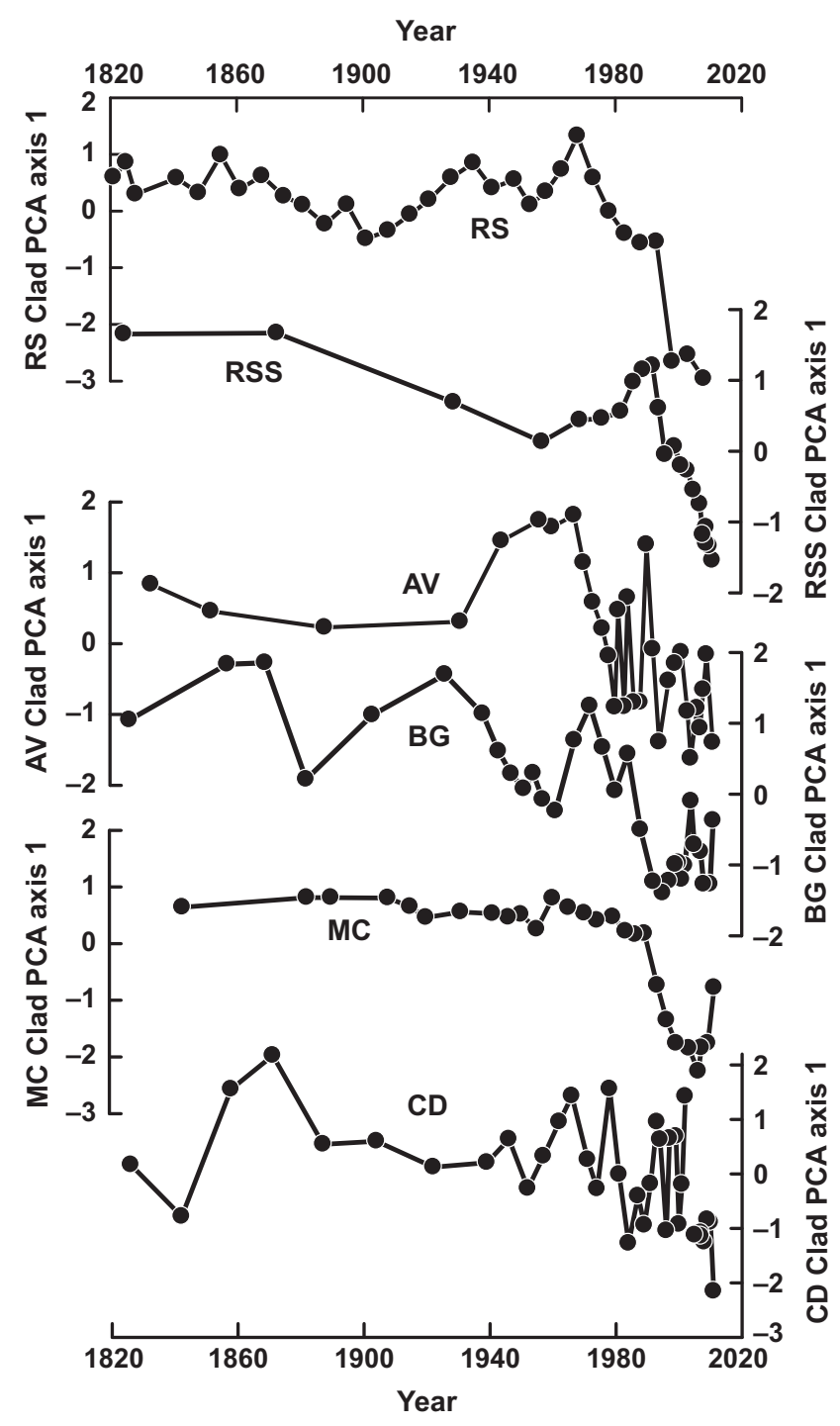

FIGURE 6 Comparison of Cladocera principal components analysis (PCA) axis 1 sample scores (standardized to mean variance using $z$-scores) plotted against estimated ${ }^{210} \mathrm{~Pb}$ dates for the six study lakes. Lake name abbreviations: Río Seco (RS), Río Seco Superior (RSS), Aguas Verdes (AV), Borreguil (BG), Mosca (MC) and Cuadrada (CD)

\section{DISCUSSION}

We identified air temperature and SPI (proxy of Saharan dust deposition) or WNAO as the best predictor variables for changes in primary production (chlorophyll-a) in all six study lakes. In some lakes, precipitation and SPI were deemed to be significant predictors of chlorophyll-a. Ice-cover duration is probably the most striking factor influencing alpine lake ecology (Thompson, Kamenik, \& Schmidt, 2005) and it is a key response variable to climate change (Adrian et al., 2009). A longer ice-free season increases light availability and mean water temperature, while also increasing water lake residence time through reduced inflows but enhanced melting of snow and weathering (increasing lake solute inputs; Preston et al., 2016; Sommaruga-Wögrath et al., 1997). These processes may enhance

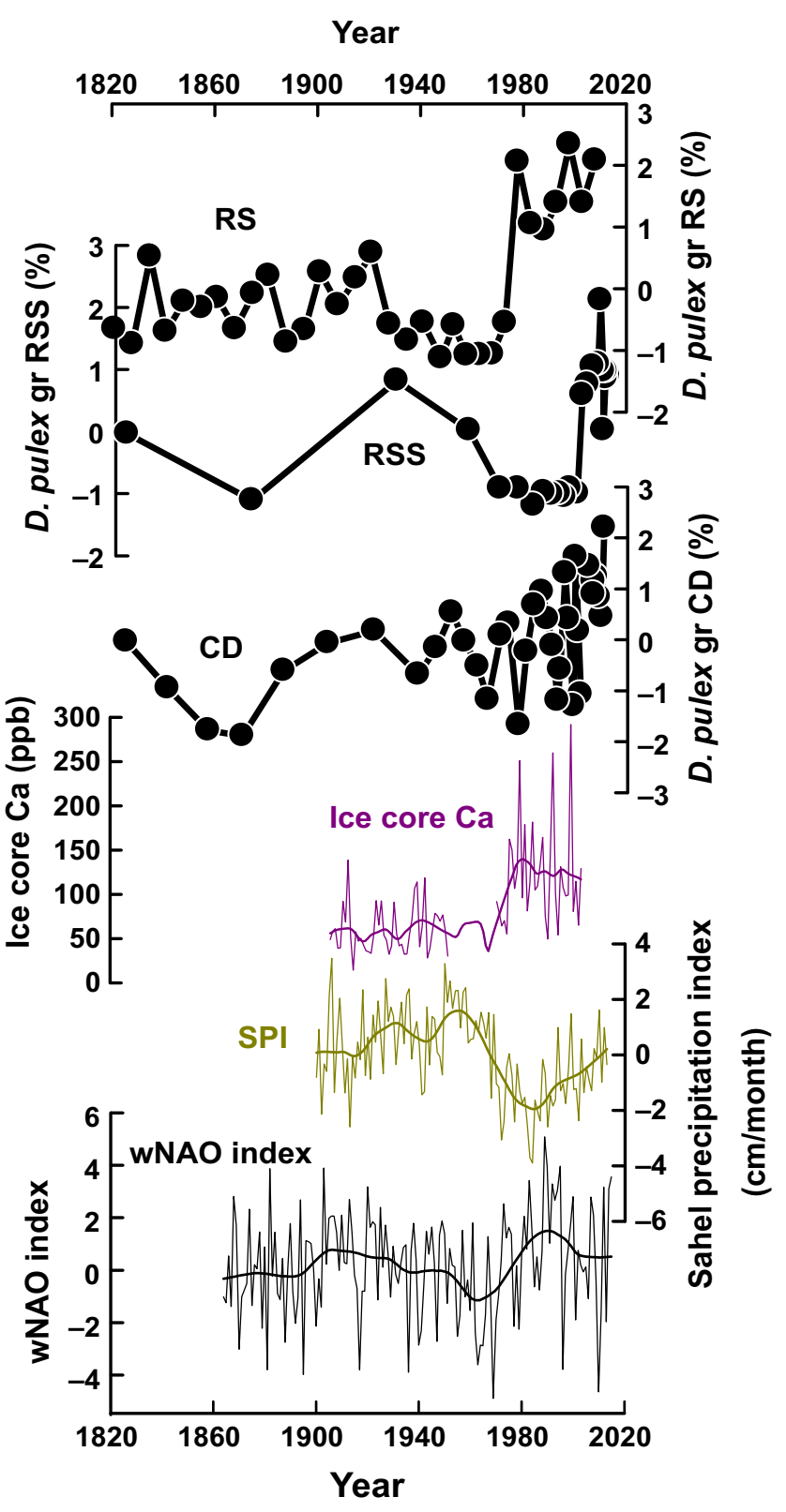

FIGURE 7 Comparison of Daphnia pulex gr. percent relative abundance (standardized to mean variance using z-scores) over time for RS, RSS and CD lakes, with the ice core Ca record (ppb), the SPI (Sahel precipitation index, $\mathrm{cm}$ per month) and the wNAO index. A LOESS smoother (span $=0.2$ ) was applied to the climate indices and the Ca record to improve the clarity of the figure and highlight trends. Lake name abbreviations: Río Seco (RS), Río Seco Superior (RSS) and Cuadrada (CD) [Colour figure can be viewed at wileyonlinelibrary.com]

biological production in Sierra Nevada lakes, and a longer growing season could also increase annual biomass accumulation (Fee, Shearer, DeBruyn, \& Schindler, 1992). Sierra Nevada lakes do not stratify and nutrient recycling, likely enhanced by warmer temperatures (Wilhelm \& Adrian, 2008), occurs throughout the ice-free period. Higher annual primary production with warming may be reflected in the sedimentary chlorophyll- $a$ data. Moreover, a decrease in $\mathrm{P}$ adsorption capacity of shore dry sediment in some 
TABLE 3 Summary of results from both the redundancy analyses (RDA) with cladoceran assemblages as response variable, and the model selection analyses predicting the PCA axis 1 score of the cladoceran assemblages for each of the study lakes

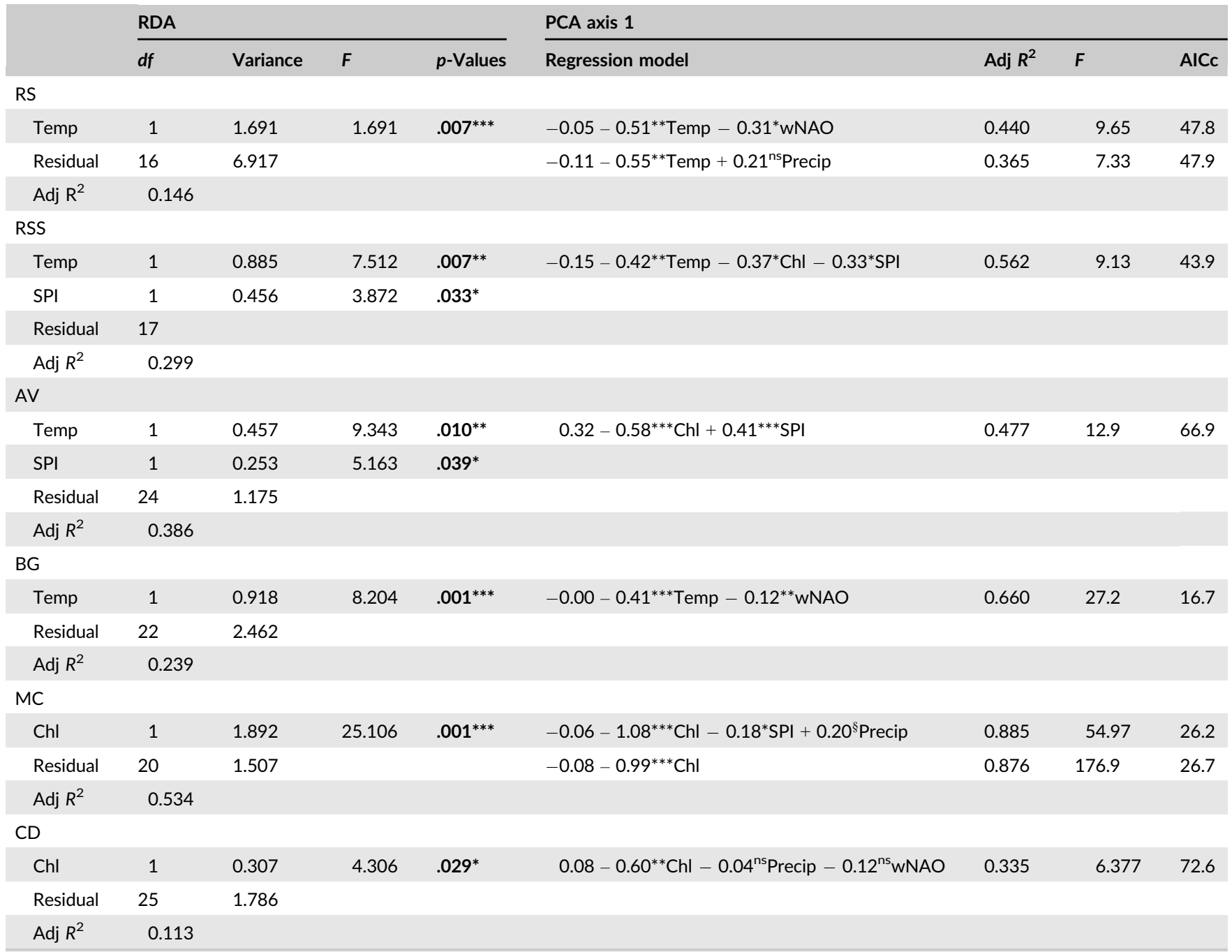

Lake name abbreviations: Río Seco (RS), Río Seco Superior (RSS), Aguas Verdes (AV), Borreguil (BG), Mosca (MC), and Cuadrada (CD).

Forward/backward selection was used to select the explanatory variables for the RDA that were $z$-score transformed to standardize to mean variance. The best models according to the Akaike's information criterion (AICC) values for the PCA are shown. Predictor variables for both analyses include: Temp, Madrid air temperature; Precip, San Fernando precipitation; SPI, Sahel precipitation index; Chl, chlorophyll- $a$ record; wNAO, winter NAO index. Only selected predictor variables for the RDA are shown. Adj $R^{2}$, adjusted $R^{2}$.

Significance levels: $* * * p<.001 ; * * .001<p<.01 ; * .01<p<.05 ;{ }^{\S} .05<p<.1 ;{ }^{\text {ns }} p>.1$.

Significant $p$-values are shown in bold for the RDA.

TABLE 4 Results of model selection analyses predicting Daphnia pulex gr. abundance in RS, RSS, and CD lakes

\begin{tabular}{|clllr} 
& Response variable & Regression model & Adj $R^{2}$ & AICc \\
\hline RS lake & & & & \\
\hline 1 & D. pulex gr. & $-0.00-0.57^{* *} \mathrm{SPI}+0.34^{\S} \mathrm{WNAO}$ & 0.620 & 14.9 \\
\hline 2 & & $-0.06-0.59^{* *} \mathrm{SPI}-0.48^{\S}$ Precip & 0.598 & 13.7 \\
\hline RSS lake & & & & 46.5 \\
\hline 1 & D. pulex gr. & $-0.03+0.93^{*} \mathrm{Chl}$ & 0.261 & 7.02 \\
\hline CD lake & & & 52.61 \\
\hline 1 & D. pulex gr. & $-0.03+0.50^{* *} \mathrm{Chl}+0.06^{\mathrm{ns}} \mathrm{WNAO}$ & 0.223 & 5.74 \\
\hline
\end{tabular}

The best models as determined by the Akaike's information criterion (AICC) values are shown. Explained variables were $z$-score transformed prior to analyses. Precip, San Fernando precipitation; SPI, Sahel precipitation index; Chl, chlorophyll-a record; wNAO, winter NAO index. Adj $R^{2}$, Adjusted $R^{2}$. Only significant models are presented in the table. Significance levels: $* * * p<.001 ; * * .001<p<.01 ; * .01<p<.05 ;{ }^{\S} .05<p<.1 ;{ }^{\text {ns }} p>.1$. 
Sierra Nevada lakes (de Vicente et al., 2010) may further enhance primary production by increasing $\mathrm{P}$ availability for algal growth due to increased exposure of lake sediment to air. In addition, there is growing evidence from annual to multiyear $(>10)$ studies that P-rich dust input exerts a notable influence on primary production in oligotrophic lakes (e.g., Brahney, Ballantyne, Kociolek, Leavitt, \& Farmer, 2015; Brahney, Mahowald, Ward, Ballantyne, \& Neff, 2015) including Mediterranean alpine lakes such as lakes in the Pyrenees and the Sierra Nevada (Camarero \& Catalan, 2012; Morales-Baquero, PulidoVillena et al., 2006). In this respect, Jiménez-Espejo et al. (2014) also suggest that increasing Saharan dust inputs may have enhanced Río Seco Lake primary production both in the Early Holocene and the past 400 years. Our centennial-scale study supports previous work in the Sierra Nevada. Thus, the intensification of warming and of delivery of P-rich Saharan input since the 1970s has resulted in a combined effect of increasing the primary production of Sierra Nevada lakes.

The main shift within the cladoceran sedimentary assemblages of each study lake occurred during the latter half of the 20th century, and is coincident with trends in regional air temperature (MAAT Madrid) and sedimentary chlorophyll-a concentrations. These two independent measurements were deemed to be the best predictor variables of the cladoceran assemblage changes for all lakes (Table 3). The principal cladoceran shift also occurs concurrently with the increase in atmospheric Ca deposition since 1980 onward as well as with the period of maximum change in the two proxies for atmospheric Ca deposition (wNAO index and SPI).

The combined effect of rising temperatures and prolonged drought beginning in the 1970s (Figure 3) has led to a reduction of snow in the Sierra Nevada region (Bonet, Pérez-Luque, \& PérezPérez, 2016; Pérez-Luque, Pérez-Pérez, \& Bonet, 2016), and likely also to shorter ice-cover periods, warmer waters, and water level decreases in most of the study lakes (Morales-Baquero, Carrillo et al., 2006; Pérez-Martínez et al., 2007). Moreover, Southern Spain suffered acute periods of drought during the late-1980s and 1990s, as warmer and drier climatic conditions became more pronounced (Udelhoven, Stellmes, del Barrio, \& Hill, 2009). These climatic changes may have compounded the change in cladoceran assemblage that have occurred in each study lake since the 1990s (Figures 5 and 6). Indeed, the onset of cladoceran assemblage changes in most lakes occurs at the end of a wet period, during the last decades of the 19th century, and the rise in temperature at the beginning of the 20th century (Figure 3). Warming-related changes in Sierra Nevada lakes suggest a process that began over a century ago, that has intensified in the past $\sim 50$ years.

Several mechanisms associated with warming may explain the observed cladoceran assemblage shifts. For example, A. quadrangularis and C. sphaericus are both well represented in the sedimentary assemblages of the study lakes, and have different habitat preferences. Chydorus sphaericus is principally associated with shallow or littoral habitats (Korhola, 1999), but frequently enter the planktonic zone (Davidson, Sayer, Perrow, Bramm, \& Jeppesen, 2010; de Eyto \& Irvine, 2001; Walseng, Hessen, Halvorsen, \& Schartau, 2006), while A. quadrangularis is principally associated with bottom mud substrata and/or benthic habitats (Tremel, Frey, Yan, Somers, \& Pawson, 2000; Whiteside, Williams, \& White, 1978). In other regions, water level changes have been reported to significantly affect lake zones and therefore habitat quality and quantity (Levi et al., 2016; Nevalainen et al., 2013). However, our Sierra Nevada study lakes are small, clear water, shallow, and littoral-dominated systems with no clear differentiation between littoral and profundal zones. Moreover, based on the sedimentary biological assemblages, these lakes have likely always been shallow and they have experienced little change in water level, in contrast with the extensively studied deep, closed basin, La Caldera Lake. UVR is an important environmental factor in high mountain lakes. In fact, planktonic invertebrates in Sierra Nevada show clear pigmentation of melanin (D. pulicaria) and carotenoids (Mixodiaptomus laciniatus) and routinely inhabit the lower part of the water column during daytime (Carrillo, Sánchez-Castillo, \& Cruz-Pizarro, 1991). UVR exposure may have recently increased in these lakes due to reduced water levels, adversely affecting littoral species (Nevalainen, 2012; Vinebrooke \& Leavitt, 1999). However, at the same time many other factors are likely decreasing UVR penetration via dissolved organic carbon (DOC) changes occurring during the period of lake level reduction, that is, primary production enhancement associated with climate change, dust deposition, or evapoconcentration (Mladenov et al., 2011; Morris et al., 1995; Psenner, 1999). Unfortunately, we are unable to ascertain the effect of water level reduction on underwater UVR in these lakes and its potential role as a driver of cladoceran changes.

In our study, the shift from C. sphaericus to A. quadrangularis may be due to climate-related factors rather than habitat preference. For instance, C. sphaericus is associated with lakes with longer periods of ice-cover and low water temperatures and is therefore typified as a cold-tolerant species, whereas A. quadrangularis is associated with more favorable climatic conditions (Bigler, Heiri, Krskova, Lotter, \& Sturm, 2006; Catalan et al., 2009; Nováková et al., 2013). The shorter ice-cover periods and warmer waters in Sierra Nevada following the 1970s likely favored A. quadrangularis to the detriment of $C$. sphaericus. In addition, lake water residence time likely increased with the onset of a warmer and drier climate resulting in reduced inflows, potentially favoring taxa with larger body size and lower growth rates, such as $A$. quadrangularis.

The timing of cladoceran assemblage changes is generally consistent with regional air temperature increases, precipitation decreases, and dust deposition increases (Figures 3, 5 and 6). However, discrepancies in the timing may be attributed to lake-specific factors (Thompson et al., 2005). For example, the change in cladoceran assemblage at 1900 was evident in all lakes with the exception of $\mathrm{AV}$. The lack of an earlier biological change in AV may be due to its geographical setting, as it is the highest elevation study lake and is proximal to the largest, most persistent snow patches in Sierra Nevada, which deliver cold water to AV throughout the ice-free period. Therefore, AV has a relatively high water renewal time, experiences very little change in water level, and has lower water temperatures than the other study lakes (i.e., nearby RS is located at 
a similar altitude), features that may explain the lake's delayed response to regional air temperature warming. However, these snow patches have receded and/or disappeared in warm and dry years as the Sierra Nevada region has increasingly experienced in recent decades.

In two of our study lakes, chlorophyll- $a$ concentrations were identified as an important explanatory variable of cladoceran change (Table 3). The strong relationship between cladoceran assemblages and chlorophyll- $a$ in these Sierra Nevada lakes may be a consequence of the strong influence of temperature, rather than a direct effect of the chlorophyll- $a$ increase. Therefore, the increase (or arrival) of $A$. quadrangularis in each study lake may signal the onset of more favorable environmental conditions for growth in terms of water temperature, a longer growing season, and food availability, relative to $C$. sphaericus, which is tolerant of less favorable growing conditions (e.g., colder, ultraoligotrophic waters) in alpine lakes (Bigler et al., 2006; Harmsworth, 1968; Lotter, Birks, Hofmann, \& Marchetto, 1997; Whiteside, 1970). In central European lakes, C. sphaericus has been found in sediment records from the Late-Glacial (Frey, 1958) and was a dominant taxon during the Last Glacial Maximum (Hofmann, 1991), with its highest abundance prior to rapid warming following the last glacial period (Nováková et al., 2013). The decrease in C. sphaericus may be due to stronger competition with taxa less well adapted to cold conditions such as $A$. quadrangularis, which increased in relative abundance with the onset of recent warming. It is plausible that warmer water temperatures, longer growing seasons, and increased primary production allowed more specialized taxa such as A. quadrangularis to thrive, and may have also favored open water filter feeders such as Daphnia spp.

Daphnia is a keystone species in many freshwater ecosystems due to its intermediate trophic position and its high efficiency at filtering phytoplankton (Brooks \& Dodson, 1965; Persson, Brett, Vrede, \& Ravet, 2007). Although Daphnia spp. were not a dominant component of the Sierra Nevada assemblages, with the exception of $C D$, their presence, and recent increases in relative abundance are nevertheless ecologically important. The high values of Saharan Ca deposition, high air temperatures, and low precipitation over the past few decades coincide with the significant Daphnia increase in RS (since 1970) and in CD (since 1900 and most pronounced after $\sim 1980$; Figures 3, 5 and 7).

Significant correlations between Daphnia and Saharan input drivers SPI and wNAO (Table 2) and the identification of SPI as the best predictor variable of Daphnia abundance in RS support the hypothesis that increased Saharan dust deposition throughout the 20th century are partially responsible for increases in Daphnia. Low lake water Ca concentrations can impair Daphnia growth and reproduction, and the naturally low $\mathrm{Ca}$ concentrations of Sierra Nevada lakes (Table 1 ) have likely been limiting for daphniids (Ashforth \& Yan, 2008; Hessen, Alstad, \& Skardal, 2000). Furthermore, those lakes that have experienced recent Daphnia increases (RS, BG, and $\mathrm{CD})$ are particularly low in $\mathrm{Ca}(<1.5 \mathrm{mg} / \mathrm{L})$ and potentially sensitive to $\mathrm{Ca}$ enrichment (Table 1). In contrast, RSS with a higher Ca concentration, recorded minimal changes in Daphnia relative abundances through time. Lake Ca concentration can be significantly affected by
Saharan Ca input in Sierra Nevada lakes (Pulido-Villena et al., 2006), thus Daphnia is significantly correlated with Saharan input drivers in the three lakes and SPI is the best Daphnia predictor in RS. In addition to the increase in atmospheric input, increased $\mathrm{Ca}$ concentrations due to evapoconcentration (Pulido-Villena et al., 2006), and also longer exposure to Saharan dust with increased water residence time and a longer ice-free period, have all likely occurred in recent decades.

Increased relative abundances of Daphnia in the low alkalinity lakes of Sierra Nevada represents a distinct ecological signal of recent environmental changes in this region, contrasting with the recent declines of Daphnia linked to the declines in Ca concentration that are a legacy of acid deposition in many Canadian softwater lakes (Jeziorski, Paterson, \& Smol, 2012; Jeziorski et al., 2008). Sierra Nevada is not particularly affected by acid deposition; instead, the Ca-rich Saharan deposition is a major contributing factor to the aquatic ecosystem dynamics in this region (Morales-Baquero \& Pérez-Martínez, 2016; Pey et al., 2013).

In addition to Saharan dust metrics, Daphnia increases coincide with increases in chlorophyll-a. This proxy for primary production was identified as the best driver of Daphnia changes in RSS and CD. As previously mentioned, the relationship between Daphnia and chlorophyll- $a$ in Sierra Nevada lakes can be a consequence of the relationship between temperature and chlorophyll-a (Table 2). In this case, there are several mechanisms that can explain the positive influence of warming on Daphnia development. Warmer waters and longer growing seasons have likely been advantageous to relatively large cladoceran species such as D. pulicaria in our study lakes, consistent with the conclusions of previous studies in Sierra Nevada lakes (Morales-Baquero, Carrillo et al., 2006; Pérez-Martínez et al., 2013) and with long-term trends of Daphnia increases associated with warming reported in several studies (Jeziorski et al., 2015; Luoto \& Nevalainen, 2013; Luoto, Oksman, \& Ojala, 2015). In Sierra Nevada, hydraulic washout can be an important process for Daphnia loss in these lakes. However, the warmer and drier climate of the past decades could favor Daphnia population growth through an increase in lake water residence time.

It is also possible that an increase in food availability (i.e., increased primary production) favored the herbivorous $D$. pulex gr. in these lakes as other studies have identified increases in Daphnia related to increased algal production (Jeziorski et al., 2015; Korhola \& Rautio, 2001). Villar-Argaiz, Medina-Sánchez, and Carrillo (2002) and Villar-Argaiz et al. (2012) indicate food quantity and high seston C:P values to limit Daphnia development in La Caldera Lake of Sierra Nevada and observed an enhancement of Daphnia populations in exceptionally high atmospheric load years. If this is the case, both warming and Saharan P input would be the ultimate drivers of cladoceran change; however, this is not possible to determine based solely on sedimentary chlorophyll- $a$ trends.

In addition to climate and Saharan $\mathrm{P}$ inputs, there are a variety of other factors that may have contributed to increases in chlorophyll-a, including both human activities and atmospheric nitrogen $(\mathrm{N})$ inputs. Although there are differences among the Sierra Nevada 
study lakes in their level of anthropogenic disturbance, in general they have been minimally affected by human activity. Furthermore, despite the differences in disturbance levels, the similar increases in sedimentary chlorophyll- $a$ exhibited by all of the study lakes in recent decades suggest that increased primary production is not directly associated with human disturbances. It is possible that some of the observed changes may be attributed to dust from local sources such as regional agriculture. However, Morales-Baquero and Pérez-Martínez (2016) show that Saharan dust represents around $85 \%$ of the total dust input (local and long-range) in the lowlands and foothills of Sierra Nevada. Furthermore, the study lakes are located at an elevation above the planetary boundary layer (PBL) in this region, and therefore the influence of regional agriculture should be low relative to Saharan dust, given that long-range transported material is mobilized in the free troposphere, whereas local deposition is mobilized by turbulence into the PBL (Morales-Baquero \& Pérez-Martínez, 2016). Similarly, although $\mathrm{N}$ deposition, derived from agriculture and fossil fuel use, can act as a potential driver of changes in remote lake ecosystems (Bergström \& Jansson, 2006), in the Sierra Nevada mountain region, $\mathrm{N}$ deposition is very low (mean dry and wet deposition of TN during the ice-free period of 2001 and 2002 were 4.5 and $3.8 \mathrm{mmol} / \mathrm{m}^{2}$, respectively), relative to other Mediterranean zones (Morales-Baquero, Pulido-Villena et al., 2006) and heavily industrialized areas in central Europe (Holland, Lee-Taylor, Nevison, \& Sulzman, 2005). N deposition mainly occurs as wet deposition (i.e., during the ice-cover period in Sierra Nevada lakes), and therefore likely affects lake biota to a lesser extent than the high $\mathrm{P}$ inputs throughout the ice-free period. The high delivery of $\mathrm{P}$ rich Saharan dust during the past 50 years mainly occurs in springsummer, and better explains (along with climate-related factors) the increasing trends in chlorophyll- $a$. This corroborates the findings of Morales-Baquero, Pulido-Villena, et al. (2006) who reported that chlorophyll- $a$ concentrations were significantly influenced by Saharan dust deposition in Sierra Nevada lakes. Camarero and Catalan (2012) also highlight the influence of fertilization by African atmospheric $P$ deposition over the past two decades on algal growth in the Pyrenean lake district. It is likely that climate-driven limnological changes, together with increased delivery of P-laden dust, have resulted in notable increases in chlorophyll- $a$ across the Sierra Nevada lakes.

Based on our data, we conclude that Sierra Nevada lakes have recently undergone changes that are consistent with a regional-scale response to a warmer and drier climate together with increases in Saharan dust inputs ( $\mathrm{Ca}$ and $\mathrm{P}$ ). Increases in atmospheric $\mathrm{P}$ and $\mathrm{Ca}$ deposition have likely affected primary production and cladoceran assemblage composition, specifically the increase of Daphnia in remote, shallow Sierra Nevada lakes. Saharan dust deposition has important ecological implications for aquatic systems across many regions of the world and warrants further exploration.

\section{ACKNOWLEDGEMENTS}

We are grateful to all our colleagues for their assistance in core collection. We thank AEMET and San Fernando Naval Base of the Spanish
Army for providing meteorological data and Dr. María Jesús EstebanParra from the Department of Applied Physics (University of Granada) for climate data. We also thank Dr. Susanne Preunkert from the Laboratory of Glaciology and Geophysics of Environment (University of Grenoble, France) for providing calcium data. The authors are grateful to Dr. Atte Korhola and ECRU (University of Finland) for contributing to the cladoceran analysis of RS Lake and Dr. Miguel Alonso for helping with the identification of cladoceran taxa. Financial support was provided by MMA Project 87/2007, MICINN Project CGL201123483, and Programa Nacional de Movilidad de Recursos Humanos de Investigación Grant (MICINN) to C. Pérez-Martínez and a FPU fellowship to L. Jiménez from the Spanish Ministry of Education and Science, as well as a Natural Sciences and Engineering Research Council grant to John P. Smol. Finally, we thank the journal reviewers for their detailed and constructive comments on the manuscript.

\section{ORCID}

Laura Jiménez (iD http://orcid.org/0000-0002-8768-987X

Kathleen M. Rühland (D) http://orcid.org/0000-0003-3994-3666

Adam Jeziorski iD http://orcid.org/0000-0001-7701-7247

John P. Smol iD http://orcid.org/0000-0002-2499-6696

Carmen Pérez-Martínez iD http://orcid.org/0000-0001-8777-4487

\section{REFERENCES}

Adrian, R., O'Reilly, C. M., Zagarese, H., Baines, S. B., Hessen, D. O., Keller, W., ... Winder, M. (2009). Lakes as sentinels of climate change. Limnology and Oceanography, 54, 2283-2297.

Alewell, C., Manderscheid, B., Meesenburg, H., \& Bittersohl, J. (2000). Environmental chemistry - Is acidification still an ecological threat? Nature, 407, 856-857.

Anderson, R. S., Jiménez-Moreno, G., Carrión, J. S., \& Pérez-Martínez, C. (2011). Holocene vegetation history from Laguna de Río Seco, Sierra Nevada, southern Spain. Quaternary Science Reviews, 30, 1615-1629.

Appleby, P. G. (2001). Chronostratigraphic techniques in recent sediments. In W. M. Last, \& J. P. Smol (Eds.), Tracking environmental change using lake sediments volume 1: Basin analysis, coring, and chronological techniques (pp. 171-203). Dordrecht, The Netherlands: Kluwer Academic Publishers.

Appleby, P. G., \& Oldfield, F. (1978). The calculation of $210 \mathrm{~Pb}$ dates assuming a constant rate of supply of unsupported $210 \mathrm{~Pb}$ to the sediment. Catena, 5, 1-8.

Ashforth, D., \& Yan, N. D. (2008). The interactive effects of calcium concentration and temperature on the survival and reproduction of Daphnia pulex at high and low food concentrations. Limnology and Oceanography, 53, 420-432.

Barea-Arco, J., Pérez-Martínez, C., \& Morales-Baquero, R. (2001). Evidence of a mutualistic relationship between an algal epibiont and its host, Daphnia pulicaria. Limnology and Oceanography, 46, 871881.

Bartoń, K. (2014). MuMln: Multi-model inference. R package version 1.10.0. Retrieved from http://CRAN.R-project.org/package=MuMln.

Bennett, K. D. (1996). Determination of the number of zones in a biostratigraphical sequence. New Phytologist, 132, 155-170.

Bergström, A. K., \& Jansson, M. (2006). Atmospheric nitrogen deposition has caused nitrogen enrichment and eutrophication of lakes in the northern hemisphere. Global Change Biology, 12, 635-643. 
Bigler, C., Heiri, O., Krskova, R., Lotter, A. F., \& Sturm, M. (2006). Distribution of diatoms, chironomids and cladocera in surface sediments of thirty mountain lakes in south-eastern Switzerland. Aquatic Sciences, 68, 154-171.

Bonet, F. J., Pérez-Luque, A. J., \& Pérez-Pérez, R. (2016). Trend analysis (2000-2014) of the snow cover by satellite (MODIS sensor). In R. Zamora, A. J. Pérez-Luque, F. J. Bonet, J. M. Barea-Azcón \& R. Aspizua (Eds.), Global change impacts in Sierra Nevada: Challenges for conservation (pp. 43-46), Sevilla: Consejería de Medio Ambiente y Ordenación del Territorio, Junta de Andalucía.

Brahney, J., Ballantyne, A. P., Kociolek, P., Leavitt, P. R., \& Farmer, G. L. (2015). Ecological changes in two contrasting lakes associated with human activity and dust transport in western Wyoming. Limnology and Oceanography, 60, 678-695.

Brahney, J., Mahowald, N., Ward, D. S., Ballantyne, A. P., \& Neff, J. C. (2015). Is atmospheric phosphorus pollution altering global alpine Lake stoichiometry? Global Biogeochemical Cycles, 29, 1369-1383.

Brooks, J. L., \& Dodson, S. I. (1965). Predation, body size, and composition of plankton. Science, 150, 28-35.

Burnham, K. P., \& Anderson, D. R. (2002). Model selection and multimodel inference: A practical information-theoretic approach. New York, NY, USA: Springer-Verlag.

Camarero, L., \& Catalan, J. (2012). Atmospheric phosphorus deposition may cause lakes to revert from phosphorus limitation back to nitrogen limitation. Nature Communication, 3, 1118.

Camarero, L., Catalan, J., Pla, S., Rieradevall, M., Jiménez, M., Prat, N., ... Vilanova, R. (1995). Remote mountain lakes as indicators of diffuse acidic and organic pollution in the lberian peninsula (AL:PE 2 studies). Water, Air and Soil Pollution, 85, 487-492.

Carlson, T. N., \& Prospero, J. M. (1972). The large-scale movement of saharan air outbreaks over the northern equatorial Atlantic. Journal of Applied Meteorology, 11, 283-297.

Carrillo, P., Sánchez-Castillo, P., \& Cruz-Pizarro, L. (1991). Coincident zooplankton and phytoplankton diel migrations in a high mountain lake (La Caldera, Sierra Nevada, Spain). Archive für Hydrobiologie, 122, 57-67.

Castillo-Martín, A. (2009). Las lagunas de Sierra Nevada. Granada, Spain: Universidad de Granada.

Catalan, J., Barbieri, M. G., Bartumeus, F., Bitusik, P., Botev, I., Brancelj, A., ... Ventura, M. (2009). Ecological thresholds in European alpine lakes. Freshwater Biology, 54, 2494-2517.

Chiapello, I., Moulin, C., \& Prospero, J. M. (2005). Understanding the long-term variability of African dust transport across the Atlantic as recorded in both Barbados surface concentrations and large-scale total ozone mapping spectrometer (TOMS) optical thickness. Journal of Geophysical Research, 110, D18S10.

D'Almeida, G. A. (1986). A model for Saharan dust transport. Journal of Climate and Applied Meteorology, 24, 903-916.

Davidson, T. A., Sayer, C. D., Perrow, M., Bramm, M., \& Jeppesen, E. (2010). The simultaneous inference of zooplanktivorous fish and macrophyte density from sub-fossil cladoceran assemblages: A multivariate regression tree approach. Freshwater Biology, 55, 546-564.

de Eyto, E., \& Irvine, K. (2001). The response of three chydorid species to temperature, $\mathrm{pH}$ and food. Hydrobiologia, 459, 165-172.

de Vicente, I., Andersen, F. Ø., Hansen, H. C. B., Cruz-Pizarro, L., \& Jensen, H. S. (2010). Water level fluctuations may decrease phosphate adsorption capacity of the sediment in oligotrophic high mountain lakes. Hydrobiologia, 651, 253-264.

Diaz, H. F., Grosjean, M., \& Graumlich, L. (2003). Climate variability and change in high elevation regions: Past, present and future. Climatic Change, 59, 1-4.

Esteban-Parra, M. J., Rodrigo, F. S., \& Castro-Díez, Y. (1998). Spatial and temporal patterns of precipitation in Spain for the period 1880 1992. International Journal of Climatology, 18, 1557-1574.
Fee, E. J., Shearer, J. A., DeBruyn, E. R., \& Schindler, E. U. (1992). Effects of lake size on phytoplankton photosynthesis. Canadian Journal of Fisheries and Aquatic Sciences, 49, 2445-2459.

Fischer, J. M., Olson, M. H., Williamson, C. E., Everhart, J. C., Hogan, P. J., Mack, J. A., ... Vinebrooke, R. D. (2011). Implications of climate change for Daphnia in alpine lakes: Predictions from long-term dynamics, spatial distribution, and a short-term experiment. Hydrobiologia, 676, 263-277.

Frey, D. G. (1958). The late glacial cladoceran fauna of small lake. Archiv für Hydrobiologie, 54, 209-275.

Frey, D. (1986). Cladoceran analysis. In B. E. Berglund (Ed.), Handbook of Holocene palaeoecology and palaeohydrology (pp. 667-692). Chichester, UK: Wiley.

García-Jurado, F., Jiménez-Gómez, F., \& Gómez, F. (2011). Effects of a dry period on the limnological characteristics of a Mediterranean high mountain lake. Limnetica, 30, 5-16.

Gerten, D., \& Adrian, R. (2000). Climate-driven changes in spring plankton dynamics and the sensitivity of shallow polymictic lakes to the North Atlantic Oscillation. Limnology and Oceanography, 45, 10581066.

Greenaway, P. (1985). Calcium balance and molting in the Crustacea. Biological Reviews, 60, 425-454.

Grimm, E. C. (2004). Tilia and TG view version 2.0.2. Springfield, IL, USA: Illinois State Museum, Research and Collection Center.

Guieu, C., \& Thomas, A. (1996). Saharan aerosol: From the soil to the ocean. In S. Guerzoni \& R. Chester (Eds.), The impact of desert dust across the Mediterranean (pp. 207-216). Dordrecht: Kluwer Academic Publisher.

Hammer, Ø., Harper, D. A. T., \& Ryan, P. D. (2001). PAST: Paleontological statistics software package for education and data analysis. Palaeontologia Electronica, 4, 1-9.

Harmsworth, R. V. (1968). The developmental history of Blelham Tarn (England) as shown by animal microfossils, with special reference to the Cladocera. Ecological Monographs, 38, 223-241.

Hessen, D. O., Alstad, N. E. W., \& Skardal, L. (2000). Calcium limitation in Daphnia magna. Journal of Plankton Research, 22, 553-568.

Hofmann, W. (1991). Stratigraphy of Chironomidae (Insecta: Diptera) and Cladocera (Crustacea) in Holocene and Wurm sediments from Lac du Bouchet (Haute Loire, France). Documents du C.E.R.L.A.T. Mémoires, 2, 363-386.

Holland, E. A., Lee-Taylor, J., Nevison, C., \& Sulzman, J. (2005). Global N cycle: Fluxes and $\mathrm{N}_{2} \mathrm{O}$ mixing ratios originating from human activity. Data set. Retrieved from http://www.daac.ornl.gov from Oak Ridge National Laboratory Distributed Active Archive Center, Oak Ridge, Tennessee, USA.

Hurrell, J. W. (1995). Decadal trends in the North Atlantic Oscillation: Regional temperature and precipitation. Science, 269, 676679.

Hurrell, J., National Center for Atmospheric Research Staff (eds). Last modified 17 March 2017. The Climate Data Guide: Hurrell North Atlantic Oscillation (NAO) Index (station-based). Retrieved from https://climatedataguide.ucar.edu/climate-data/hurrell-north-atlanticoscillation-nao-index-station-based

Jeziorski, A., Tanentzap, A. J., Yan, N. D., Paterson, A. M., Palmer, M. E., Korosi, J. B., ... Smol, J. P. (2015). The jellification of north temperate lakes. Proceedings of the Royal Society B, 282, 20142449.

Jeziorski, A., Paterson, A. M., \& Smol, J. P. (2012). Changes since the onset of acid deposition among calcium-sensitive cladoceran taxa within softwater lakes of Ontario, Canada. Journal of Paleolimnology, 48, 323-337.

Jeziorski, A., \& Yan, N. D. (2006). Species identity and aqueous calcium concentrations as determinants of calcium concentrations of freshwater crustacean zooplankton. Canadian Journal of Fisheries and Aquatic Sciences, 63, 1007-1013. 
Jeziorski, A., Yan, N. D., Paterson, A. M., Desellas, A. M., Turner, M. A. Jeffries, D. S., ... Smol, J. P. (2008). The widespread threat of calcium decline in fresh waters. Science, 322, 1374-1377.

Jiménez, L., Romero-Viana, L., Conde-Porcuna, J. M., \& Pérez-Martínez, C. (2015). Sedimentary photosynthetic pigments as indicators of climate and watershed perturbations in an alpine lake in southern Spain. Limnetica, 34, 439-454.

Jiménez-Espejo, F. J., García-Alix, A., Jiménez-Moreno, G., Rodrigo-Gámiz, M., Anderson, R. S., Rodríguez-Tovar, F. J., ... Pardo-Igúzquiza, E. (2014). Saharan aeolian input and effective humidity variations over western Europe during the Holocene from a high altitude record. Chemical Geology, 374-375, 1-12.

Jiménez-Espejo, F. J., Martinez-Ruiz, F., Sakamoto, T., lijima, K., GallegoTorres, D., \& Harada, N. (2007). Paleoenvironmental changes in the western Mediterranean since the last glacial maximum: High resolution multiproxy record from the Algero-Balearic basin. Palaeogeography, Palaeoclimatology, Palaeoecology, 246, 292-306.

Jiménez-Moreno, G., García-Alix, A., Hernández-Corbalán, M. D., Anderson, R. S., \& Delgado-Huertas, A. (2013). Vegetation, fire, climate and human disturbance history in the southwestern Mediterranean area during the late Holocene. Quaternary Research, 79, 110-122.

Kamenik, C., Szeroczyńska, K., \& Schmidt, R. (2007). Relationships among recent Alpine Cladocera remains and their environment: Implications for climate-change studies. Hydrobiologia, 594, 33-46.

Korhola, A. (1999). Distribution patterns of Cladocera in subarctic Fennoscandian lakes and their potential in environmental reconstruction. Ecography, 22, 357-373.

Korhola, A., \& Rautio, M. (2001). Cladocera and other branchiopod crustaceans. In J. P. Smol, H. J. B. Birks, \& W. M. Last (Eds.), Tracking environmental change using lake sediments. volume 4: Zoological indicators (pp. 5-41). Dordrecht, the Netherlands: Kluwer Academic Publishers.

Kurek, J., Korosi, J. B., Jeziorski, A., \& Smol, J. P. (2010). Establishing reliable minimum count sizes for cladoceran microfossils sampled from lake sediments. Journal of Paleolimnology, 44, 603-612.

Lequy, E., Conil, S., \& Turpault, M. P. (2012). Impacts of Aeolian dust deposition on European forest sustainability: A review. Forest Ecology and Management, 267, 240-252.

Levi, E. E., Bezirci, G., Çakiroğlu, A. i., Turner, S., Bennion, H., Kernan, M., ... Beklioğlu, M. (2016). Multi-proxy palaeoecological responses to water-level fluctuations in three shallow Turkish lakes. Palaeogeography, Palaeoclimatology and Palaeoecology, 449, 553-566.

Linares-Cuesta, E., Olofsson, L., \& Sánchez-Castillo, P. (2007). Comunidades de diatomeas epipélicas en las lagunas de alta montaña de Sierra Nevada (Granada, España). Limnetica, 26, 99-113.

Lionello, P. (2012). The climate of the Mediterranean region: From the past to the future. Amsterdam, the Netherlands: Elsevier.

Lotter, A. F., Birks, H. J. B., Hofmann, W., \& Marchetto, A. (1997). Modern diatom, cladocera, chironomid, and chrysophyte cyst assemblages as quantitative indicators for the reconstruction of past environmental conditions in the Alps. I. Climate. Journal of Paleolimnology, 18 395-420.

Loÿe-Pilot, M. D., Martin, J. M., \& Morelli, J. (1986). Influence of Saharan dust on the rain acidity and atmospheric input to the Mediterranean. Nature, 321, 427-428.

Luoto, T. P., \& Nevalainen, L. (2013). Climate change impacts on zooplankton and benthic communities in Lake Unterer Giglachsee (Niedere Tauern Alps, Austria). International Review of Hydrobiology, 98, 80-88.

Luoto, T. P., \& Nevalainen, L. (2016). Solar and atmospheric forcing on mountain lakes. Science of the Total Environment, 566-567, 168174.

Luoto, T. P., Oksman, M., \& Ojala, A. E. K. (2015). Climate change and bird impact as drivers of High Arctic pond deterioration. Polar Biology, 38, 357-368.
Manca, M., Torretta, B., Comoli, P., Amsinck, S. L., \& Jeppesen, E. (2007). Major changes in trophic dynamics in large, deep sup-alpine Lake Maggiore from 1940s to 2002: A high resolution comparative palaeo-neolimnological study. Freshwater Biology, 52, 2256-2269.

Michelutti, N., Blais, J. M., Cumming, B. F., Paterson, A. M., Rühland, K., Wolfe, A. P., \& Smol, J. P. (2010). Do spectrally- inferred determinations of chlorophyll $a$ reflect trends in lake trophic status? Journal of Paleolimnology, 43, 205-217.

Michelutti, N., \& Smol, J. P. (2016). Visible spectroscopy reliably tracks trends in paleo-production. Journal of Paleolimnology, 56, 253-265.

Michelutti, N., Wolfe, A. P., Vinebrooke, R. D., Rivard, B., \& Briner, J. P. (2005). Recent primary production increases in arctic lakes. Geophysical Research Letters, 32, L19715.

Mladenov, N., Sommaruga, R., Morales-Baquero, R., Laurion, I., Camarero, L., Diéguez, M. C., ... Reche, I. (2011). Dust inputs and bacteria influence dissolved organic matter in clear alpine lakes. Nature Communications, 2, 405.

Morales-Baquero, R., Carrillo, P., Barea-Arco, J., Pérez-Martínez, C., \& Villar-Argaiz, M. (2006). Climate-driven changes on phytoplankton-zooplankton coupling and nutrient availability in high mountain lakes of Southern Europe. Freshwater Biology, 51, 989-998.

Morales-Baquero, R., Carrillo, P., Reche, I., \& Sánchez-Castillo, P. (1999). Nitrogen-phosphorus relationship in high mountain lakes: Effects of the size of catchment basins. Canadian Journal of Fisheries and Aquatic Sciences, 56, 1809-1817.

Morales-Baquero, R., \& Conde-Porcuna, J. M. (2000). Effect of the catchment areas on the abundance of zooplankton in high mountain lakes of Sierra Nevada (Spain). Verhandlungen der Internationale Vereinigung für theoretische und angewandte Limnologie, 27, 1-5.

Morales-Baquero, R., \& Pérez-Martínez, C. (2016). Saharan versus local influence on atmospheric aerosol deposition in the southern Iberian Peninsula: Significance for $\mathrm{N}$ and $\mathrm{P}$ inputs. Global Biogeochemical Cycles, 30, 501-513.

Morales-Baquero, R., Pulido-Villena, E., \& Reche, I. (2006). Atmospheric inputs of phosphorus and nitrogen to the southwest Mediterranean region: Biogeochemical responses of high mountain lakes. Limnology and Oceanographic, 51, 830-837.

Morales-Baquero, R., Pulido-Villena, E., \& Reche, I. (2013). Chemical signature of Saharan dust on dry and wet atmospheric deposition in the south-western Mediterranean region. Tellus, Series B: Chemical and Physical Meteorology, 65, 18720.

Morris, D. P., Zagarese, H., Williamson, C. E., Balseiro, E. G., Hargreaves, B. R., Modenutti, B., ... Queimalinos, C. (1995). The attenuation of solar UV radiation in lakes and the role of dissolved organic carbon. Limnology and Oceanography, 40, 1381-1391.

Moulin, C., \& Chiapello, I. (2004). Evidence of the control of summer atmospheric transport of African dust over the Atlantic by Sahel sources from TOMS satellites (1979-2000). Geophysical Research Letters, 31, L02107.

Moulin, C., \& Chiapello, I. (2006). Impact of human-induced desertification on the intensification of Sahel dust emission and export over the last decades. Geophysical Research Letters, 33, L18808.

Moulin, C., Lambert, C. E., Dulac, F., \& Dayan, U. (1997). Control of atmospheric export of dust from North-Africa by the North Atlantic oscillation. Nature, 387, 691-694.

Mulitza, S., Heslop, D., Pittauerova, D., Fischer, H. W., Meyer, I., Stuut, J.-B., ... Schulz, M. (2010). Increase in African dust flux at the onset of commercial agriculture in the Sahel region. Nature, 466, 226-228.

Nevalainen, L. (2012). Distribution of benthic microcrustaceans along a water depth gradient in an Austrian Alpine lake-Sedimentary evidence for niche separation. Limnologica, 42, 65-71.

Nevalainen, L., Helama, S., \& Luoto, T. P. (2013). Hydroclimatic variations over the last millennium in eastern Finland disentangled by fossil Cladocera. Palaeogeography, Palaeoclimatology, Palaeoecology, 378, 13-21. 
Nogués-Bravo, D., López-Moreno, J. I., \& Vicente-Serrano, S. M. (2012). Climate change and its impact. In I. N. Vogiatzakis (Ed.), Mediterranean Mountain Environments (pp. 185-201). Chichester, UK: WileyBlackwell.

Nováková, K., van Hardenbroek, M., \& van der Knaap, W. O. (2013). Response of subfossil Cladocera in Gerzensee (Swiss Plateau) to early Late Glacial environmental change. Palaeogeography, Palaeoclimatology, Palaeoecology, 391, 84-89.

Oksanen, J., Blanchet, F. G., Friendly, M., Kindt, M., Legendre, P., McGlinn, D., ... Solymos, P. (2015). Vegan: Community ecology package. R package version 2.4-0. Retrieved from http://CRAN.R-project. org/package=vegan

Oliva, M., \& Gómez Ortiz, A. (2012). Late Holocene environmental dynamics and climate variability in a Mediterranean high mountain environment (Sierra Nevada, Spain) inferred from lake sediments and historical sources. The Holocene, 22, 915-927.

Oliva, M., Gómez-Ortiz, A., \& Schulte, L. (2010). Tendencia a la aridez en Sierra Nevada desde el Holoceno Medio inferida a partir de sedimentos lacustres. Boletín de la Asociación de Geógrafos Españoles, 52, 27-42.

Oliva, M., Schulte, L., \& Gómez-Ortiz, A. (2011). The role of aridification in constraining the elevation range of Holocene solifluction processes and associated landforms in the periglacial belt of the Sierra Nevada (Southern Spain). Earth Surface Processes and Landforms, 36, 12791291.

Pauli, H., Gottfried, M., Dullinger, S., Abdaladze, O., Akhalkatsi, M., Benito Alonso, J. L., ... Grabherr, G. (2012). Recent plant diversity changes on Europe's mountain summits. Science, 336, 353-355.

Pérez-Luque, A. J., Pérez-Pérez, R., \& Bonet, F. J. (2016). Climate change over the last 50 years in Sierra Nevada. In R. Zamora, A. J. PérezLuque, F. J. Bonet, J. M. Barea-Azcón \& R. Aspizua (Eds.), Global change impacts in Sierra Nevada: Challenges for conservation (pp. 24 26), Sevilla: Consejería de Medio Ambiente y Ordenación del Territorio, Junta de Andalucía.

Pérez-Martínez, C., Barea-Arco, J., Conde-Porcuna, J. M., \& MoralesBaquero, R. (2007). Reproduction strategies of Daphnia pulicaria population in a high mountain lake of Southern Spain. Hydrobiologia, 594, 75-82.

Pérez-Martínez, C., Jiménez, L., Moreno, E., \& Conde-Porcuna, J. M. (2013). Emergence pattern and hatching cues of Daphnia pulicaria (Crustacea, Cladocera) in an alpine lake. Hydrobiologia, 707, 47-57.

Perga, M.-A., Desmet, M., Enters, D., \& Reyss, J.-L. (2010). A century of bottom-up and top-down-driven changes on a lake planktonic food web: A paleoecological and paleoisotopic study of Lake Annecy, France. Limnology and Oceanography, 55, 803-816.

Persson, J., Brett, M. T., Vrede, T., \& Ravet, J. L. (2007). Food quantity and quality regulation of trophic transfer between primary producers and a keystone grazer (Daphnia) in pelagic freshwater food webs. Oikos, 116, 1152-1163.

Pey, J., Querol, X., Alastuey, A., Forastiere, F., \& Stafoggia, M. (2013). African dust outbreaks over the Mediterranean Basin during 20012011: $\mathrm{PM}_{10}$ concentrations, phenomenology and trends, and its relation with synoptic and mesoscale meteorology. Atmospheric Chemistry and Physics, 13, 1395-1410.

Preston, D. L., Caine, N., McKnight, D. M., Williams, M. W., Hell, K., Miller, M. P., ... Johnson, P. T. J. (2016). Climate regulates alpine lake ice cover phenology and aquatic ecosystem structure. Geophysical Research Letters, 43, 5353-5360.

Preunkert, S., \& Legrand, M. (2013). Towards a quasi-complete reconstruction of past atmospheric aerosol load and composition (organic and inorganic) over Europe since 1920 inferred from Alpine ice cores. Climate of the Past, 9, 1403-1416.

Prospero, J. M., Ginoux, P., Torres, O., Nicholson, S. E., \& Gill, T. E. (2002). Environmental characterization of global sources of atmospheric soil dust identified with the NIMBUS 7 total ozone mapping spectrometer (TOMS) absorbing aerosol product. Reviews of Geophysics, 40, 1002.

Prospero, J. M., \& Lamb, P. J. (2003). African droughts and dust transport to the Caribbean: Climate change implications. Science, 302, 1024 1027.

Psenner, R. (1999). Living in a dusty world: Airborne dust as a key factor for Alpine Lakes. Water, Air and Soil Pollution, 112, 217-227.

Puga, E., Díaz de Federico, A., Nieto, J. M., \& Díaz Puga, M. A. (2007). Petrología, evolución geodinámica y georrecursos del Espacio Natural de Sierra Nevada. Estudios Geológicos, 63, 19-40.

Pulido-Villena, E., Reche, I., \& Morales-Baquero, R. (2006). Significance of atmospheric inputs of calcium over the southwestern Mediterranean region: High mountain lakes as tools for detection. Global Biogeochemical Cycles, 20, GB2012.

R Development Core Team (2015). R: A language and environment for statistical computing. Vienna, Austria: R Foundation for Statistical Computing.

Reche, I., Ortega-Retuerta, E., Romera, O., Pulido-Villena, E., MoralesBaquero, R., \& Casamayor, E. O. (2009). Effect of Saharan dust inputs on bacterial activity and community composition in Mediterranean lakes and reservoirs. Limnology and Oceanography, 54, 869 879.

Reche, I., Pulido-Villena, E., Conde-Porcuna, J. M., \& Carrillo, P. (2001). Photoreactivity of dissolved organic matter from high-mountain lakes of Sierra Nevada, Spain. Artic, Antartic, and Alpine Research, 33, 426434.

Reche, I., Pulido-Villena, E., Morales-Baquero, R., \& Casamayor, E. O. (2005). Does ecosystem size determine aquatic bacterial richness? Ecology, 86, 1715-1722.

Ridame, C., \& Guieu, C. (2002). Saharan input of phosphate to the oligotrophic water of the open western Mediterranean Sea. Limnology and Oceanography, 47, 856-869.

Sánchez-Castillo, P. M., Cruz-Pizarro, L., \& Carrillo, P. (1989). Caracterización del fitoplancton de las lagunas de alta montaña de Sierra Nevada (Granada, España) en relación a las características físicoquímicas del medio. Limnetica, 5, 37-50.

Sánchez-Castillo, P. M., Linares-Cuesta, J. E., \& Fernández-Moreno, D. (2008). Changes in epilithic diatom assemblages in a Mediterranean high mountain lake (Laguna de La Caldera, Sierra Nevada, Spain) after a period of drought. Journal of Limnology, 67, 49-55.

Saros, J. E., Interlandi, S. J., Wolfe, A. P., \& Engstrom, D. R. (2003). Recent changes in the diatom community structure of lakes in the Beartooth Mountain Range, USA. Arctic, Antarctic, and Alpine Research, 35, 18-23.

Schelske, C. L., Peplow, A., Brenner, M., \& Spencer, C. N. (1994). Lowbackground gamma counting: Applications for $210 \mathrm{~Pb}$ dating of sediments. Journal of Paleolimnology, 10, 115-128.

Schütz, L., Jaenicke, R., \& Pietrek, H. (1981). Saharan dust transport over the North Atlantic Ocean. In T. L. Pewe (Ed.), Desert dust: Origin, characteristic and effect on man (pp. 87-100). Special Paper 186, Boulder, CO: Geological Society of America.

Smol, J. P. (2008). Pollution of lakes and rivers: A paleoenvironmental perspective (2nd edn). Oxford, UK: Willey-Blackwell publishing.

Sommaruga-Wögrath, S., Koinig, K. A., Schmidt, R., Sommaruga, R., Tessadri, R., \& Psenner, R. (1997). Temperature effects on the acidity of remote alpine lakes. Nature, 387, 64-67.

Sorvari, S., Korhola, A., \& Thompson, R. (2002). Lake diatom response to recent Arctic warming in Finnish Lapland. Global Change Biology, 8, 171-181.

Staudt, M., Esteban-Parra, M. J., \& Castro-Díez, Y. (2007). Homogenization of long-term monthly Spanish temperature data. International Journal of Climatology, 27, 1809-1823.

Swap, R., Garstang, M., Greco, S., Talbot, R., \& Kållberg, P. (1992). Saharan dust in the Amazon basin. Tellus, 44B, 133-149. 
Szeroczyńska, K., \& Sarmaja-Korjonen, K. (2007). Atlas of subfossil Cladocera from Central and Northern Europe. Świecie: Friends of the Lower Vistula Society.

Thompson, R., Kamenik, C., \& Schmidt, R. (2005). Ultra-sensitive Alpine lakes and climate change. Journal of Limnology, 64, 139-152.

Tremel, B., Frey, S. E., Yan, N. D., Somers, K. M., \& Pawson, T. W. (2000). Habitat specificity of littoral Chydoridae (Crustacea, Branchiopoda, Anomopoda) in Plastic Lake, Ontario, Canada. Hydrobiologia, 432, 195-205.

Udelhoven, T., Stellmes, M., del Barrio, G., \& Hill, J. (2009). Assessment of rainfall and NDVI anomalies in Spain (1989-1999) using distributed lag models. International Journal of Remote Sensing, 30, 1961-1976.

van Breemen, N., \& Wright, R. F. (2004). History and prospect of catchment biogeochemistry: A European perspective based on acid rain. Ecology, 85, 2363-2368.

Villar-Argaiz, M., Bullejos, F. J., Medina-Sánchez, J. M., RamosRodríguez, E., Delgado-Molina, J. A., \& Carrillo, P. (2012). Disentangling food quantity and quality effects in zooplankton response to P-enrichment and UV radiation. Limnology and Oceanography, 57, 235-250.

Villar-Argaiz, M., Medina-Sánchez, J. M., \& Carrillo, P. (2002). Interannual changes in the $\mathrm{C}: \mathrm{N}: \mathrm{P}$ ratios of seston and zooplankton of a high mountain lake in Sierra Nevada, Spain. Water, Air and Soil Pollution: Focus, 2, 359-378.

Villar-Argaiz, M., Medina-Sánchez, J. M., Cruz-Pizarro, L., \& Carrillo, P. (2001). Inter- and intra-annual variability in the phytoplankton community of a high mountain lake: The influence of external (atmospheric) and internal (recycled) sources of phosphorus. Freshwater Biology, 46, 1017-1034.
Vinebrooke, R. D., \& Leavitt, P. R. (1999). Differential responses of littoral communities to ultraviolet radiation in an alpine lake. Ecology, 80, 223-237.

Walseng, B., Hessen, D. O., Halvorsen, G., \& Schartau, A. K. (2006). Major contribution from littoral crustaceans to zooplankton species richness in lakes. Limnology and Oceanography, 51, 2600-2606.

Wehausen, R., \& Brumsack, H. J. (1999). Cyclic variations in the chemical composition of eastern Mediterranean Pliocene sediments: A key for understanding sapropel formation. Marine Geology, 153, 161-176.

Whiteside, M. C. (1970). Danish Cladocera: Modern ecology and core studies. Ecological Monographs, 40, 79-118.

Whiteside, M. C., Williams, J. B., \& White, C. P. (1978). Seasonal abundance and pattern of chydorid, Cladocera in mud and vegetative habitats. Ecology, 59, 1177-1188.

Wilhelm, S., \& Adrian, R. (2008). Impact of summer warming on the thermal characteristics of a polymictic lake and consequences for oxygen, nutrients and phytoplankton. Freshwater Biology, 53, 226-237.

Williamson, C. E., Saros, J. E., Vincent, W., \& Smol, J. P. (2009). Lakes and reservoirs as sentinels, integrators, and regulators of climate change. Limnology and Oceanography, 54, 2273-2282.

How to cite this article: Jiménez L, Rühland KM, Jeziorski $A$, Smol JP, Pérez-Martínez C. Climate change and Saharan dust drive recent cladoceran and primary production changes in remote alpine lakes of Sierra Nevada, Spain. Glob Change Biol. 2018;24:e139-e158. https://doi.org/10.1111/gcb.13878 